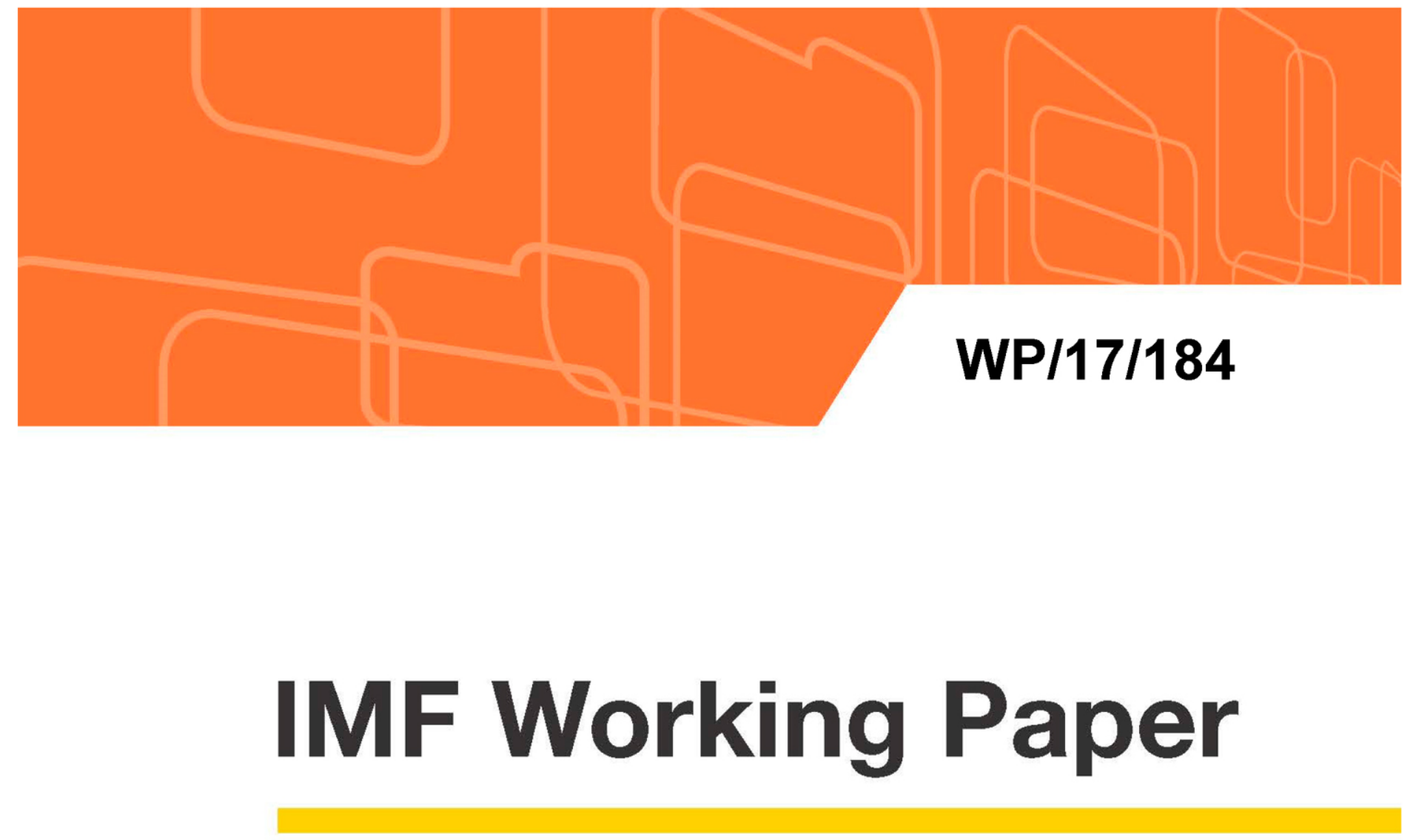

\title{
The Nonlinear Interaction Between Monetary Policy and
} Financial Stress

by Martín Saldías

IMF Working Papers describe research in progress by the author(s) and are published to elicit comments and to encourage debate. The views expressed in IMF Working Papers are those of the author(s) and do not necessarily represent the views of the IMF, its Executive Board, or IMF management. 


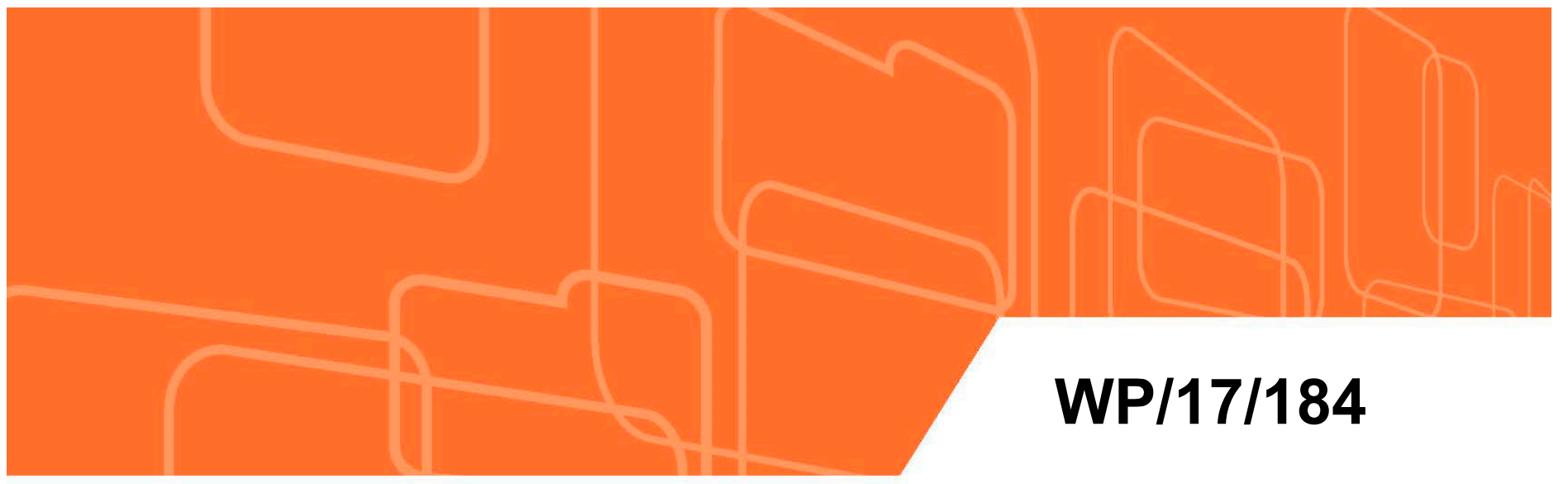

\section{IMF Working Paper}

\section{The Nonlinear Interaction Between Monetary Policy and Financial Stress}

by Martín Saldías

IMF Working Papers describe research in progress by the author(s) and are published to elicit comments and to encourage debate. The views expressed in IMF Working Papers are those of the author(s) and do not necessarily represent the views of the IMF, its Executive Board, or IMF management. 


\title{
IMF Working Paper
}

Monetary and Capital Markets Department

\section{The Nonlinear Interaction Between Monetary Policy and Financial Stress ${ }^{1}$ Prepared by Martín Saldías}

\author{
Authorized for distribution by Gaston Gelos
}

August 2017

\section{IMF Working Papers describe research in progress by the author(s) and are published to elicit comments and to encourage debate. The views expressed in IMF Working Papers are those of the author(s) and do not necessarily represent the views of the IMF, its Executive Board, or IMF management.}

\begin{abstract}
This paper analyzes the nonlinear relationship between monetary policy and financial stress and its effects on the transmission of shocks to output. Results from a Bayesian Threshold Vector Autoregression (TVAR) model show that the effects of monetary policy shocks on output growth are stronger during normal times than during times of financial stress. Monetary policy shocks are effective to ease stressed financial conditions, but have limited ability to fully contain the buildup of vulnerabilities. These results have important policy implications for central banks' countercyclical policies under different financial conditions and for "lean against the wind" policies to address financial vulnerabilities.
\end{abstract}

JEL Classification Numbers: C32, E44, G01, G2

Keywords: Monetary policy, financial stress, Bayesian threshold vector autoregression Author's E-Mail Address: msaldias@imf.org

\footnotetext{
${ }^{1}$ The author is very grateful to Stephen Cecchetti, Karl Habermeier, Dong He, Hibiki Ichiue, Tommaso Mancini-Griffoli and Machiko Narita for extensive discussions and to Martin Čihák, Gaston Gelos, Andrés González, Stefan Laseen, Mario Mansilla, Haroon Mumtaz, Norbert Metiu, Srobona Mitra, Erlend Nier, Luca Ricci, Inci Otker-Robe, Adina Popescu, Tahsin Saadi-Sedik and IMF and ECB seminar participants for comments and suggestions. Excellent research assistance by Zohair Alam is gratefully acknowledged.
} 


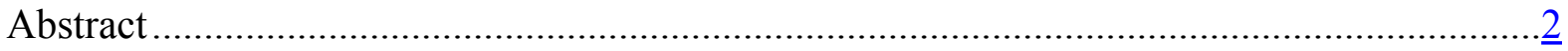

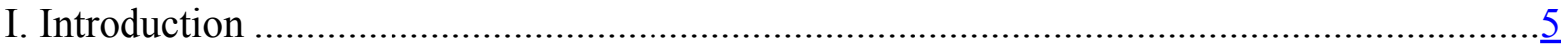

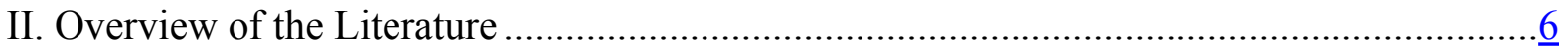

A. Regime-Dependent Monetary Transmission ................................................... $\underline{6}$

B. Monetary Policy and Financial Stress .......................................................

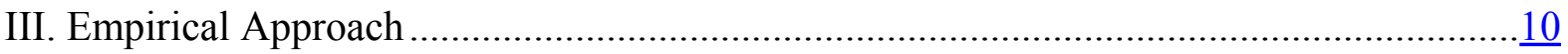

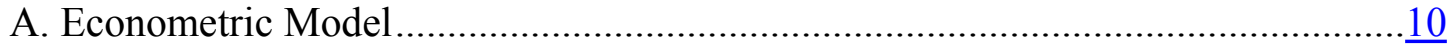

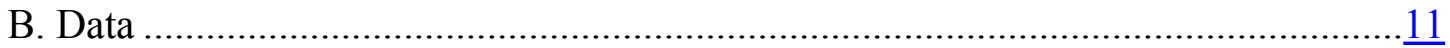

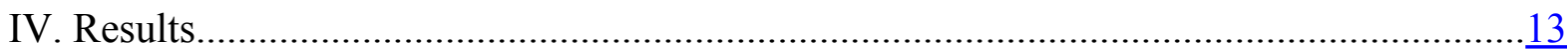

A. Financial Stress Regimes ...................................................................... $\frac{13}{14}$

B. Transmission Mechanism to Output Growth ..................................................

C. Monetary Policy and Financial Stress ............................................................. 16

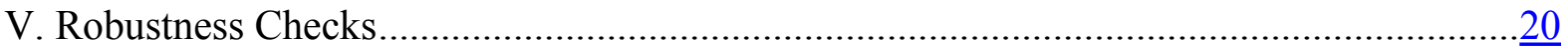

A. Alternative FSI Thresholds ................................................................... $\frac{20}{21}$

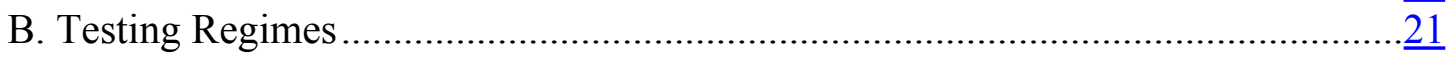

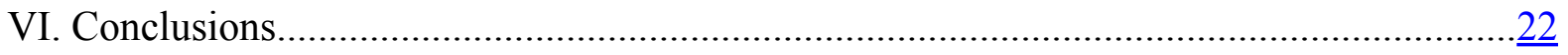

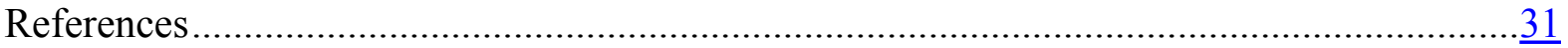

Table

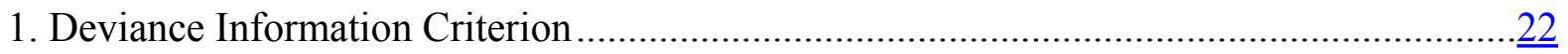

Figures

1. Financial Stress Regimes Determined by Average Distance-to-Default ...........................14

2. Impulse Response Functions - Impact of a 100 bps Monetary Policy Shock on Output

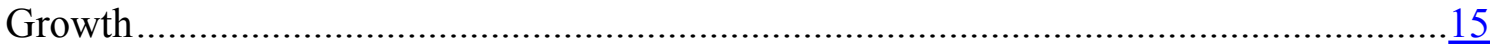

3. Differences Across Regimes-Difference in Impact of a 100 bps Monetary Policy Shock on Output Growth Threshold Variable: ADD .........................................................

4. Impulse Response Functions - Impact of a 100 bps Monetary Policy Shock on Average Distance-to-Default .................................................................................................18

5. Differences Across Regimes-Difference in Impact of 100 bps Monetary Policy Shock

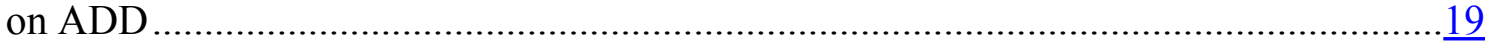

6. Maximum Impact of a 100 bps Monetary Policy Shock on Median-Average Distance-toDefault Across Regimes ............................................................................

7. Financial Stress Regimes Determined by Financial Stress Index....................................28

8. Impulse Response Functions - Impact of a 100 bps Monetary Policy Tightening on Output Growth Threshold Variable: FSI ................................................................29

9. Impulse Response Functions - Impact of a 100 bps Monetary Policy Shock on FSI .......... $\underline{30}$ 


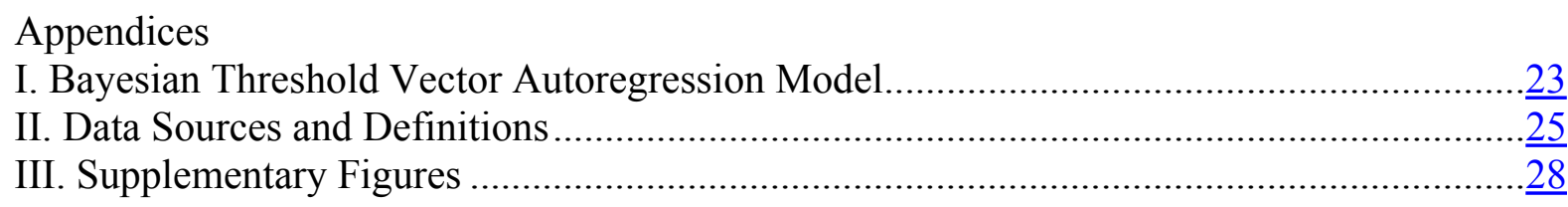

Appendix Tables

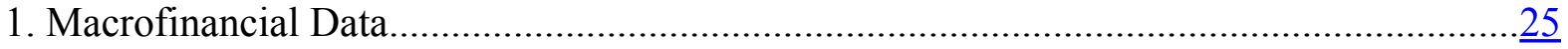

2. Financial Companies' Names and ISIN Codes.......................................................26 


\section{INTRODUCTION}

The global financial crisis prompted aggressive easing of monetary policy in advanced economies to stabilize their financial systems and protect economic activity. While financial stress was contained and financial conditions improvement were followed by radical regulatory overhaul and a more active use of macroprudential policies, additional monetary policy stimuli were needed to promote economic recovery. These developments have spurred a renewed interest in the interactions between monetary policy, financial conditions, and financial fragility.

These relationships are likely to be nonlinear. On the one hand, accommodative monetary policy, if sustained over long periods, appears to promote the buildup of financial fragilities. On the other hand, containing such a buildup of financial conditions using monetary policy through "leaning-against-the-wind" 2 policies has proven difficult, as the evidence from Sweden and Norway suggests. The transmission of monetary policy to output, in turn, seems to depend in nonlinear ways on the health of the financial sector: around financial stress episodes, stimulative policies taken by central banks appear to require a much more substantial easing of policies than around normal times. This is likely due to disruptions in the non-neoclassical set of transmission channels of monetary policy (Hatzius et al., 2010).

A number of recent studies document that monetary policy affects output growth and inflation differently under low and high financial stress regimes. Those studies also show that monetary policy shocks to financial conditions can vary under different financial regimes.

This paper contributes to this literature by empirically analyzing the interaction between monetary policy and financial stress. In particular, it addresses two main questions:

1. How do financial stress regimes affect the monetary policy transmission in four advanced economies viewed over a 30 year period?

2. Can monetary policy affect financial conditions and thus stress, and how strong is the effect under alternative financial conditions?

The contribution of this study is that it examines the indirect relationship of financial stress on the link between monetary policy and output across countries. Traditionally, this relationship has been modeled without considering financial conditions, and especially ignoring possible nonlinearities.

Another contribution of the paper is that it seeks to assess the effectiveness of monetary policy to "get in the cracks" when financial vulnerabilities arise and trigger a period of

\footnotetext{
${ }^{2}$ Leaning against the wind states that financial stability concerns should be part of the secondary objectives of monetary policy strategy as financial cycle and its interaction with the business cycle cannot be fully addressed by macroprudential policy. See Smets (2014) for an extensive discussion.
} 
financial stress. ${ }^{3}$ The policy implication of a nonlinear relationship is that central banks could be able to monitor financial conditions and the health of the financial sector and then gauge the intensity of their monetary response. At the same time, central banks would be aware of the potential implications for the financial system that may justify or not "leaning against the wind."

To answer these questions the paper uses a Bayesian Threshold-VAR estimated with monthly data for four advanced economies, the U.S., the U.K., Canada and Australia. In particular, the model includes data for the period 1984 to 2014 on industrial production, inflation, the slope of the sovereign yield curve and an Average Distance-to-Default (ADD) series, a measure of financial stress conditions based on averages of individual Distance-to-Default (DD) of the largest publicly traded banks and insurance companies. ADD is used as threshold variable and determines the switch between non-stress and stress regimes.

On the first question, the empirical results suggest that the monetary policy effects on output are stronger when the financial system is functioning well. When the financial sector is stressed, an expansionary shock to monetary policy would be less effective in stimulating output growth.

On the second question, the results show that the effect of a monetary policy shock on financial stress is considerably larger when the financial system is under stress. This means that an expansionary shock to monetary policy could get into the cracks and help help rebuild resilience of the financial system when it is needed. However, a contractionary shock to monetary policy alone is likely to have less success in mitigating financial vulnerabilities when financial conditions are relatively loose and risks to financial stability in the medium run may be building up (Adrian and Liang, 2014). This result therefore underscores the importance of macroprudential policies in dealing with financial booms.

The rest of the paper is organized as follows. Section II situates this paper in the literature that links the monetary policy transmission mechanism to economic growth and financial conditions. Section III describes the econometric TVAR model, the sample countries in the analysis and the properties of ADD as a financial stress variable. Sections IV and V discuss results and robustness checks in detail. Section IV concludes.

\section{OVERVIEW OF THE LiteratURE}

\section{A. Regime-Dependent Monetary Transmission}

Nonlinearities in the monetary transmission literature are linked to the notion that output growth reacts differently to monetary policy shocks across different regimes: These regimes in turn, are associated with sharp changes in financial conditions. Financial conditions are

\footnotetext{
${ }^{3}$ Stein (2013) uses the phrase to "get in all of the cracks" to refer to the ability of central banks to affect the behavior of banks and nonbank financial institutions through changes in interest rates in a more widespread way than supervision, regulation or other policy instruments.
} 
broadly defined by the state of financial variables that influence economic behavior and thereby the state of the economy (Hatzius et al. 2010). The literature on this topic is not new, but renewed attention has been raised by the recent global crisis (Smets, 2014).

Theoretical work on financial market frictions and nonlinearities can be traced back to Blinder (1987), Bernanke and Gertler (1989) and Bernanke et al. (1996). That literature established that negative shocks to monetary policy, tend to be amplified by weak credit market conditions and thus produce longer recessions. These models also identify potential asymmetric responses to monetary easing or tightening during upturns and downturns.

In the empirical literature, nonlinearities are modeled following two alternative approaches, Threshold Vector Autoregression (TVAR) models and Markov-switching Vector Autoregression (MS-VAR) models. MS-VAR models define different regimes by changes in the parameters that capture the transmission of shocks and their variances. ${ }^{4}$ The structural changes in TVAR models take place when a prespecified transition variable exceeds an observable critical value. In this paper I use the financial conditions variable as the transition variable and link it directly to the health of the financial sector. From a policy point of view, this modeling approach has more advantages as it allows for monitoring the financial stability measure and its regime changes over time.

Financial conditions are widely defined in the literature and include a large variety of measures. They are narrowly proxied by credit market conditions in the earlier literature and by distress in the banking sector or measures of overall distress in financial markets in more recent contributions. The latter comprise stress in the banking and the nonbanking financial sector or in securities and foreign exchange markets.

In empirical studies, monetary policy has traditionally been captured by a policy or a short term rate such as the Fed Funds Rate in the United States (U.S.) or the Main Refinancing Operations Announcement Rate in the euro area. With the zero lower bound (ZLB) becoming binding in many economies, this approach has lost some of its signaling properties; it may also distort model estimation and the interpretation of its results. Recent work is developing new measures of monetary policy stance, ${ }^{5}$ specially to support joint monetary policy and financial stability analysis.

\footnotetext{
${ }^{4}$ Results using Bayesian MS-VAR models in Hubrich and Tetlow (2015) for the U.S. and Hartmann et al. (2015) for the euro area show strong statistical support for nonlinearities in the relationship between output and financial stress. The regimes identified in these models tend to coincide with financial events in history as they rely on broad market stress indices and do not only focus on the banking or nonbanking sectors. Kaufmann and Valderrama (2010) also find support for procyclical effects of credit and asset price shocks on output growth in the two economies. Hubrich et al. (2013) provide additional evidence both for linear and nonlinear multivariate models. Eickmeier et al. (2016) and Silvestrini and Zaghini (2015) provide a comprehensive overview of the literature.

5 The Irving Fisher Committee (2015) summarizes recent contributions in this direction. Krippner (2015) reviews methods to construct measures of the stance of monetary policy in the U.S. and other countries using shadow rates obtained from yield curves.
} 
Balke (2000) pioneered the empirical work on TVAR models. Using U.S. data, he found evidence of nonlinear effects of credit conditions on the transmission mechanism and showed that effects of monetary shocks were stronger under a "tight" credit conditions regime than in a "normal" credit conditions regime. Balke used three measures of credit conditions, namely the commercial paper spread over the six-month Treasury Bill, the mix of bank loans and commercial paper in total firms' external finance, and the difference between the growth rates in the short-term debt of small and large manufacturing firms.

In applications to other economies, Calza and Sousa (2006) found similar results for the euro area, Li and St-Amant (2010) for Canada, and Atanasova (2003) for the United Kingdom (U.K.). The latter two also found some support to the hypothesis of stronger effects of monetary policy tightening compared to easing over the financial cycle. ${ }^{6}$

More recently, Fry-McKibbin and Zheng (2016) apply a TVAR model to the U.S. for the period prior to the introduction of unconventional monetary policies in 2008, and finds support for regime dependent effects from shocks to policy rates on both inflation and output growth. Financial stability is measured as financial stress, as captured by the Chicago Fed's Adjusted National Financial Conditions Index (ANFCI) 7 .This result suggests that the transmission mechanism may be impaired by generalized financial distress in addition to more narrowly defined credit conditions in the banking system or funding tensions.

Avdjiev and Zeng (2014) propose an alternative approach to analyze the interactions between credit market conditions, monetary policy, and economic activity. They use a three-regime TVAR model in which regimes are specified by the state of economic activity (namely subpar, moderate and high growth). Their results find evidence of considerable regimedependence and lead them to conclude that monetary shocks have stronger effects on output growth during periods of low economic growth, when economic agents are more likely to be credit and liquidity constrained.

Finally, Alessandri and Mumtaz (2014 and 2017) develop a Bayesian TVAR with U.S. data and provide strong econometric support for the forecasting performance of nonlinear models for output growth and inflation. To define regimes they use the National Financial Conditions Index (NFCI). Although these studies focus on the effect of shocks to the financial conditions instead of monetary policy shocks, their results confirm that nonlinear models are well equipped to account for size and impact of financial shocks in the transmission mechanism.

\footnotetext{
${ }^{6}$ Calza and Sousa (2006) use a weighted average of retail bank lending rates to households and firms as a measure of credit conditions. Atanasova (2003) relies on the corporate bond spread, as measured by the spread between the ten-year investment-grade corporate bonds and the ten-year government bond yield. Finally, Li and St-Amant introduce a broader measure of financial stress as a proxy for tensions in the Canadian credit market.

${ }^{7}$ Chicago Fed's ANFCI summarizes U.S. financial conditions in money markets, debt and equity markets, and the traditional and shadow banking systems. It is adjusted to strong correlation with current economic conditions.
} 


\section{B. Monetary Policy and Financial Stress}

As noted, the global financial crisis has triggered new interest in the question of whether monetary policy should respond to financial stability concerns. To address this question, it is important to determine first whether monetary policy has any effects on financial stability at all.

Two complementary approaches have tackled this question. One approach analyzes episodes of loose monetary policy and potential risk-taking channels. Adrian and Liang (2014), for example, argue that monetary policy accommodation can reduce stress and improve financial conditions but may also feed the buildup of financial vulnerabilities and risks to the financial system in the longer run.

The second approach is related to the nonlinear models described in the previous section. The studies in this group examine how monetary policy shocks can create or alleviate financial stress events across different financial regimes.

The bulk of the post-crisis empirical literature is related to the second approach. Adrian and Liang (2014) and Borio and Zhu (2012) outline a conceptual framework where monetary policy does not target financial stability objectives independently of its inflation and output. The objectives include pricing of risk, leverage, maturity and liquidity mismatch and interconnectedness and complexity in the financial system. In this framework, the financial system does not only comprise the banking sector but also asset markets, the shadow banking sector and the nonfinancial sector. Smets (20014) provides additional examples of theoretical approaches in the literature and introduces empirical applications.

A number of studies focus on the banking sector. Angeloni et al. (2015) show that lowering policy rates raises bank riskiness, particularly on the funding side. Similar results are found in Jiménez et al. (2014), who emphasize the interaction between lowly capitalized banks and risky firms in a low policy rate environment. Ciccarelli et al. (2015) find that the credit channel amplifies a monetary policy shock on output growth and inflation through the balance-sheets of households, firms, and banks of the U.S. and the euro area. Buch et al. (2014) challenge this result on aggregate and find that risk taking after a monetary policy loosening or an unexpected increase in property prices can be distributed heterogeneously in the banking system.

Studies that examine the direct impact of monetary policy on financial stress in a nonlinear approach are less common and include the papers reviewed in the previous section. Li and St-Amant (2010) provide evidence for Canada that contractionary monetary policy increases financial stress regardless the initial financial regime while monetary policy easing shows a significant but weaker effect. Similar results are found in Fry-McKibbin and Zheng (2016) for the U.S. data. Results in Atanasova (2003) show that monetary policy tightening deteriorates credit conditions as measures by the corporate spreads in the U.K. Finally, Avdjiev and Zeng (2014) find that the strength of the effects of monetary policy shocks on credit market conditions is similar across weak, moderate, and strong economic performance. This paper shares with them the TVAR empirical approach but innovates through the use of ADD to determine nonlinearities and extends the analysis to a multicounty framework. 


\section{EMPIRICAL APPROACH}

\section{A. Econometric Model}

The econometric method used to capture nonlinearities between monetary policy and financial stress is a Bayesian TVAR model. Following Alessandri and Mumtaz (2017), the model specification for each country is the following:

$$
\begin{aligned}
& Z_{t}=\left[c_{1}+\sum_{j=1}^{P} B_{1 j} Z_{t-j}+\Omega_{1 t}^{1 / 2} e_{t}\right]\left(1-\tilde{S}_{t}\right)+\left[c_{2}+\sum_{j=1}^{P} B_{2 j} Z_{t-j}+\Omega_{2 t}^{1 / 2} e_{t}\right] \tilde{S}_{t} \\
& \tilde{S}_{t}=1 \Leftrightarrow F S I_{t-d} \leq F S I^{*},
\end{aligned}
$$

where $Z_{t}=\left\{y_{t}, \pi_{t}, F S I_{t}\right.$, slope $\left._{t}\right\}$ is the vector that contains the four endogenous variables, namely output growth $\left(y_{t}\right)$, the inflation rate, $\left(\pi_{t}\right)$, the financial stress index $\left(F S I_{t}\right)$ and the monetary policy variable measured by the government yield curve slope (slope $)$. $\tilde{S}_{t}$ is the state variable that determines non-stress and stress regimes.

The model splits the time series into two different regimes determined by a critical level of the financial stress index. In particular, under the baseline model, financial stress index is the Average Distance-to-default (ADD) ${ }^{8}$ and therefore a stress regime is set when a lag $d$ of the financial stress index $F S I_{t-d}$ falls below ${ }^{9}$ an unobserved threshold $F S I^{*}$. Both $d$ and $F S I^{*}$ are unknown and estimated with the rest of parameters in (1).

The Bayesian approach is useful to deal with the high parameterization of this type of models as it uses loose and deliberately uninformative and atheoretical priors, which allows the model results to be still driven by data. Additional technical details are explained in Appendix I.

The shock identification is a simple recursive Cholesky ordering, where output growth and inflation are placed first as slow-moving variables. Financial stress is ordered next and the yield curve slope is ordered last. This specification is in line with the empirical literature which takes into account that both the financial stress indicator and the yield curve are fastmoving market-based variables and therefore ordered last. ${ }^{10}$

\footnotetext{
${ }^{8}$ For a description of data sources and variables see the next section.

${ }^{9}$ Alternatively, when the financial stress indices are the alternative FSI variables, the stress regime takes place when the threshold level is surpassed: $F S I_{t-d} \geq F S I^{*}$.

${ }^{10}$ As the baseline specification relies on ADD includes both market-based but also balance-sheet financial information for its construction and the slope is also a financial variable, this assumption is plausible. As a robustness check, the TVAR models were estimated changing the order of ADD to last with consistent results.
} 


\section{B. Data}

The TVAR model is applied to data for four advanced economies, namely the United States (USA), the United Kingdom (GBR), Canada (CAN) and Australia (AUS). These countries have been selected because of data quality and length and because the mandate of their monetary policy mandates include low inflation and economic growth. The model is estimated using monthly series of the four macro-financial variables for the period January 1984 - October 2014. ${ }^{11}$ Output growth is measured as the year-on-year change in industrial production; inflation rate is measured as the year-on-year change in the CPI.

\section{Monetary policy stance: The yield curve slope}

The sovereign yield curve slope (proxy for the monetary policy stance) is computed as the difference between 10-year government bond yields and the 3-month T-bill rate. ${ }^{12}$ This is especially relevant given the presence of a zero lower bound (ZLB) problem in the sample, ${ }^{13}$ when policy short term interest rates can no longer be used as the single benchmark for monetary policy stance and the ability of central banks to affect the economy and the financial sector using their balance sheets needs to be reflected.

Although monetary aggregates, other central bank's balance sheet items and shadow rates have been used to measure the monetary policy stance in the recent empirical literature, using the slope of the yield curve slope allows us to capture both conventional monetary policy and unconventional measures such as asset purchases and forward-guidance.

There is extensive empirical evidence ${ }^{14}$ of a stable and strong predictive power of the yield curve slope of economic activity, especially in recessions, both across advanced economies and emerging countries.

In particular, monetary policy easing (tightening), in the presence of price rigidities and stable inflation expectations, would tend to decrease (increase) nominal short term interest rates by more than long rates thus steepening (flattening) the yield curve slope. A steeper (flatter) slope is, in turn, associated with a transitory lower (higher) real interest rate that promotes (holds back) residential and investment spending and consumption of durable goods. ${ }^{15}$

\footnotetext{
${ }^{11}$ See Appendix I for details on data coverage and sources.

${ }^{12}$ For Australia, the short term rate is the two-year bond yield.

${ }^{13}$ With the exception of Australia.

${ }^{14}$ See Estrella et al. (2003) and references therein for a wide set of advanced economies and Mehl (2009) for emerging markets.

${ }^{15}$ It is important to note that a flattening of the slope has been associated with monetary policy easing during the ZLB, as unconventional monetary policies were designed to lower term premia, enabling the portfolio balance channel. The empirical literature shows some evidence of its positive effect on asset prices and growth
}

(continued...) 
The yield curve slope effects on financial stress have not been analyzed empirically too extensively. In this model, it is expected that a shock that steepens the slope reduces financial stress. A key important channel for this are the effects of the higher slope on the income and profits of financial institutions. In particular, Alessandri and Nelson (2015) argue that as the yield curve steepens, net interest margins increase, improving financial conditions, and promoting profitable lending. ${ }^{16}$ Borio et al. (2015) add to that the positive effect of a steep curve on larger loan-loss provisions, lower debt service costs and default probabilities that compensate the potential losses of non-interest income, driving up return on assets in the system. English et al. (2012) show large effects of changes in the slope on bank equity prices as a combination of changes in longer-term assets values, discount rates on future earnings, and expectations of future profits.

The insurance sector is highly exposed to interest rate and reinvestment risks. The long end of the yield curve matters considerably for the synchronization of their asset and liability cash flows and the need for portfolio reallocation and ultimately for their profits, especially in the life-insurance industry. As a result, a flattening of the yield curve undermines insurers' profits and triggers search for yield, which involves longer-term vulnerabilities.

\section{Average distance-to-default as financial stress index}

The baseline model is estimated using ADD as financial stress indicator. ADD is a simple average of individual forward-looking DD series of banks and insurance companies in each country computed using information from balance sheets and equity prices. ${ }^{17}$

The DD measure is part of the Contingent Claims Analysis (CCA) and is based on the Merton approach to credit risk (Crosbie and Bohn, 2003). DD is positively affected by assets' growth and negatively affected by leverage and assets volatility. Being a market-based measure, asset's value and volatility are, in turn, determined by market capitalization and stock market volatility. As DD decreases, the indicator goes closer to a point of distress in the whole financial system. Assuming a normal distribution, DD can be also mapped into probabilities of default (PD) ${ }^{18}$ in a highly nonlinear relationship.

(Baumeister and Benati, 2013) but with the caveat of them being small and short lived (Wright, 2012 and Pesaran and Smith, 2016).

${ }^{16}$ Adrian et al. (2010) use this argument as an additional mechanism whereby the yield curve slope affects economic activity. In particular, they argue that changes in the slope change credit supply given that financial intermediaries manage actively their balance sheets, providing an idea of the risk-taking channel of monetary policy and the link between financial conditions and financial stability. It is worth noting too that the effect of a steeper yield curve on bank profits is premised on the assumption of the assumption of fixed rates at both ends and the dynamic management of assets and liabilities.

${ }^{17}$ See Appendix II for details of the institutions included in the sample.

${ }^{18}$ See Crosbie and Bohn (2003) for technical details of DD series computation and Saldías (2013) for discussion about the properties of ADD series. 
ADD tracks the lower bound of system distress or equivalently the upper bound of PD, as its construction implicitly assumes perfect correlation across assets in the system. The ADD series cover the largest and most liquid publicly traded banks and insurance companies since 1984 by asset size and market capitalization, taking into account mergers and relevant corporate actions. ${ }^{19}$

The number of banks and insurers varies across countries because of the relative diversification and concentration in each sector, with more weight of banks in Australia and Canada and a more complex and diversified financial system in the U.S. and the U.K. It is also relevant to note that in general banks' ADD series tend to be lower over time for banks than for insurers due to the characteristics of their respective business in terms of leverage and asset volatility. That said, both series comove strongly due to the market-based properties of this indicator.

\section{Financial stress index}

In addition to ADD series, financial conditions and stress are identified using the Financial Stress Index (FSI) series developed by the Cardarelli et al. (2011). In contrast to ADD, these composite indicators do not aggregate stress series of individual institutions. Instead, they rather track aggregate developments in different markets such as banking, securities, and foreign exchange markets and summarize their common movements. These indices are normalized and positive and large values above the zero historical average indicate stress. They are included as a robustness check in the section below.

\section{Results}

\section{A. Financial Stress Regimes}

Figure 1 shows the estimated stress regimes as colored bars in the four economies using ADD as threshold variable. The first to notice is that the global stress regime periods are easily recognizable across countries, including the Black Monday crash, the S\&L crisis, the LTCM/Russian crisis, the dot-com bubble and more recently the post-Lehman global financial crisis.

As a result, the estimated stress regimes have a significant cross-country overlap over time. However, the regimes include additional regional and country-specific stress episodes, such as the European Exchange Rate Mechanism (ERM) and the recent European sovereign crisis in the case of the United Kingdom.

Finally, the estimated stress regimes also capture, and broadly precede the economic downturns dated by the National Bureau of Economic Research (NBER) for the United

\footnotetext{
${ }^{19}$ In particular, individual series of DD take into account entry and exit dates of financial institutions individually before aggregation.
} 
States and by the Organization of Economic Co-Operation and Development (OECD) ${ }^{20}$ for the other three countries. In most cases, output decline is embedded in the stress regime, which means that not all episodes of financial stress cause a recession.

Figure 1. Financial Stress Regimes Determined by Average Distance-to-Default

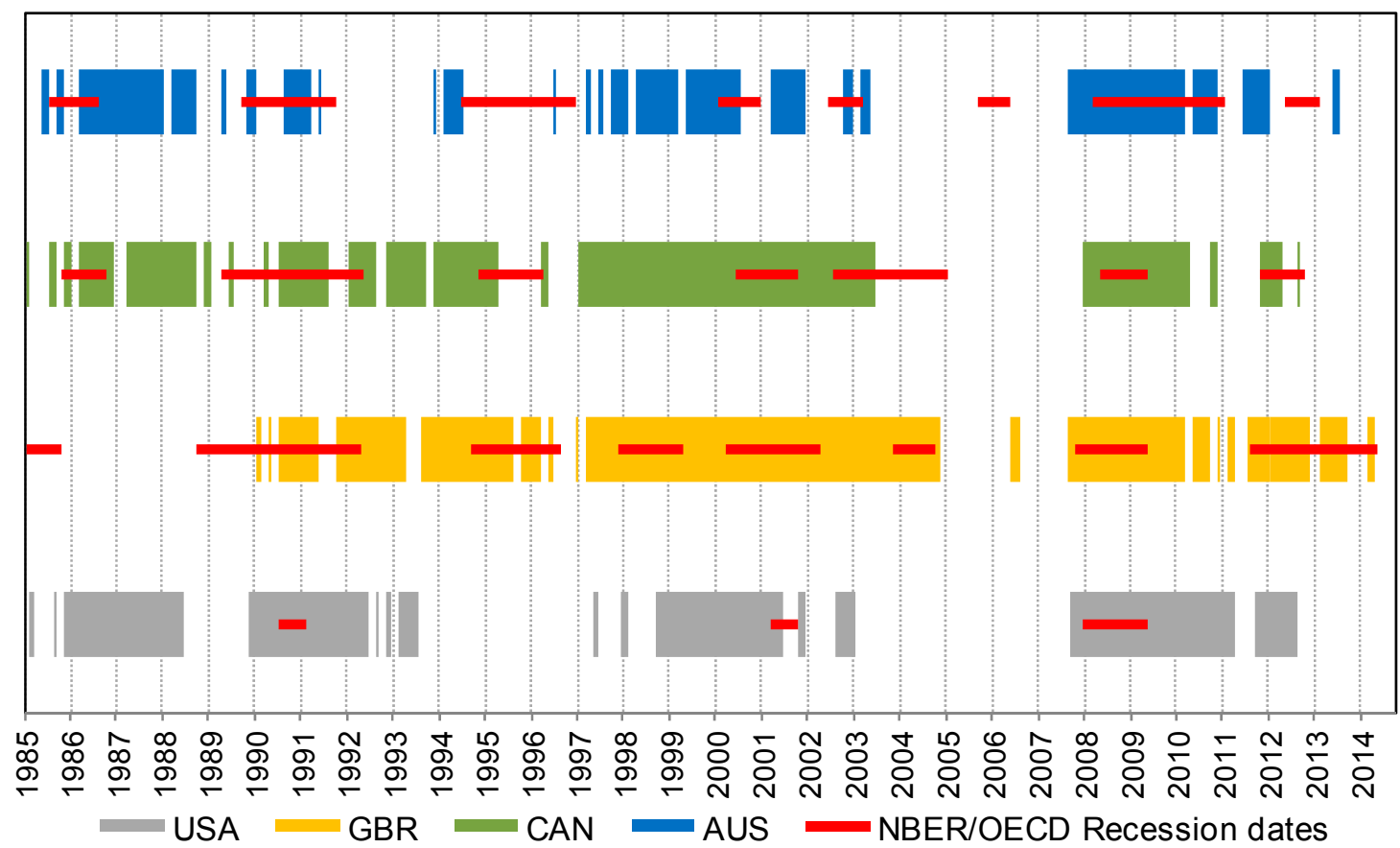

Source. Author's calculations and FRED.

Note: The colored shaded areas indicate periods of stress determined by the TVAR model. Based on data from January 1984 to October 2014 for USA, CAN, and AUS and from January 1989 to October 2014 for GBR.

\section{B. Transmission Mechanism to Output Growth}

This section reports result of the TVAR estimation that sheds light on whether output growth reacts differently to monetary policy shocks across different financial stress regimes. Figure 2 presents the estimated median impulse response (IRF) of output growth to a one-time shock of 100 basis points in the yield curve slope, equivalent to a monetary policy tightening via an interest rate hike, over 60 months in non-stress and stress regimes and their corresponding 16th and 84th percentiles for the four countries in the sample. Figure 3 shows the differences across regimes and the corresponding confidence intervals.

\footnotetext{
${ }^{20} \mathrm{http}: / /$ www.oecd.org/std/leading-

indicators/oecdcompositeleadingindicatorsreferenceturningpointsandcomponentseries.htm
} 
In line with the literature, the estimates suggest that a flatter slope leads to a hump-shaped decline in output growth across all countries and in both regimes. Focusing on the median responses, a 100 bps shock to monetary policy takes between 1 year and 18 months to reach its peak effect, producing a decline in a range of 0.6 and 1.3 percent on industrial output growth.
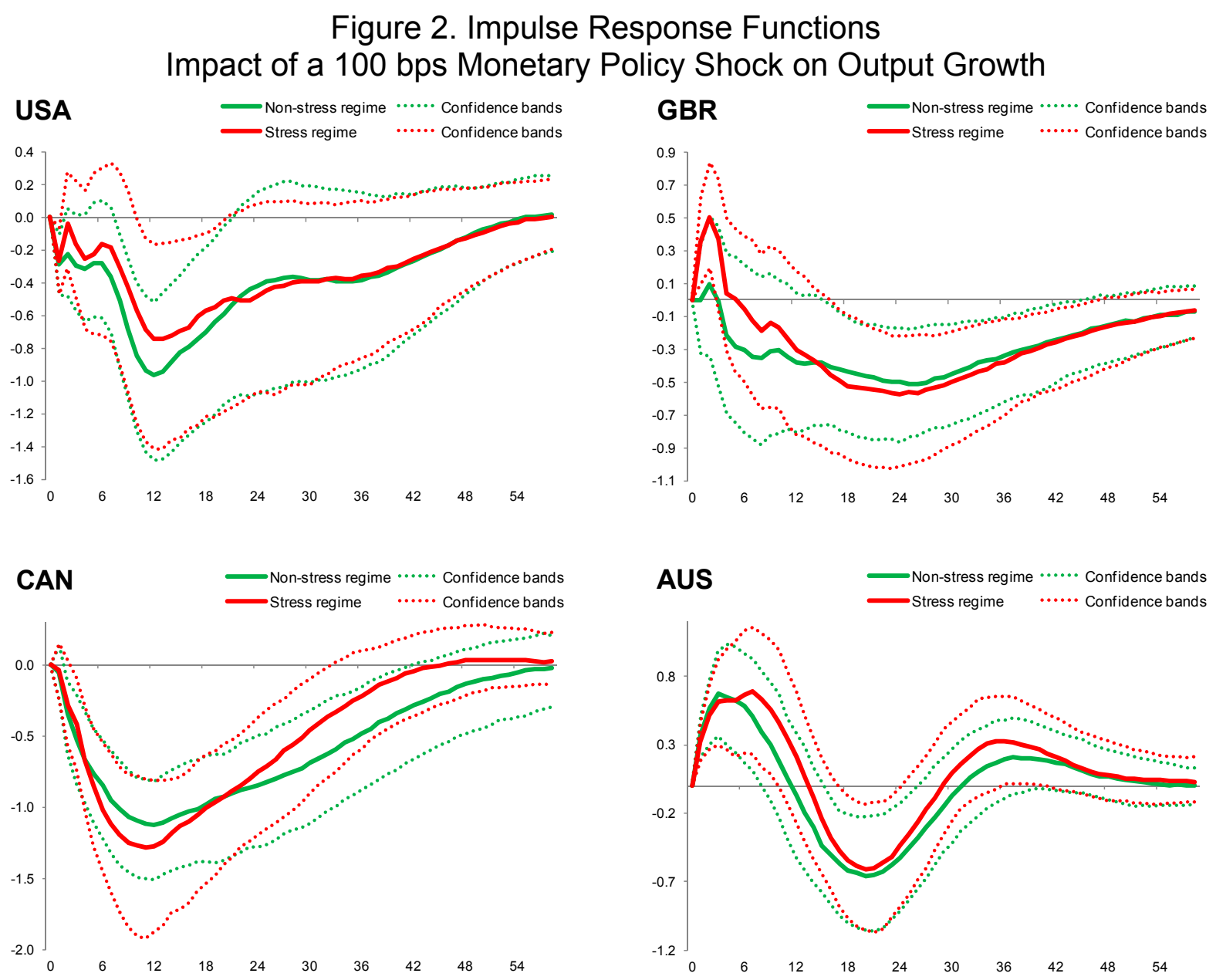

Source. Author's calculations.

Note: The panel shows impulse response functions according to the TVAR model described above to a shock of $100 \mathrm{bps}$ to the yield curve slope, which is equivalent to a monetary policy tightening via an interest rate hike. Green (red) lines and confidence bands correspond to non-stress (stress) regimes and are measured in the vertical axis in percentage points. The horizontal axis measures the months after the shock.

The quantitative differences across regimes do not seem very large but a closer look at the median effects and their differences in Figure 3 show that the contractionary effect is stronger (up to 0.3 percentage points) and relatively faster in non-stress regimes, especially within one year. This result suggests that the effect of a shock to the yield curve slope is reduced if the financial system is already under stress, reflecting that the transmission mechanism is impaired. There is some heterogeneity across countries because of different financial system structures, but the results are broadly consistent. 
Figure 3. Differences Across Regimes-

Difference in Impact of a 100 bps Monetary Policy Shock on Output Growth

Threshold Variable: ADD
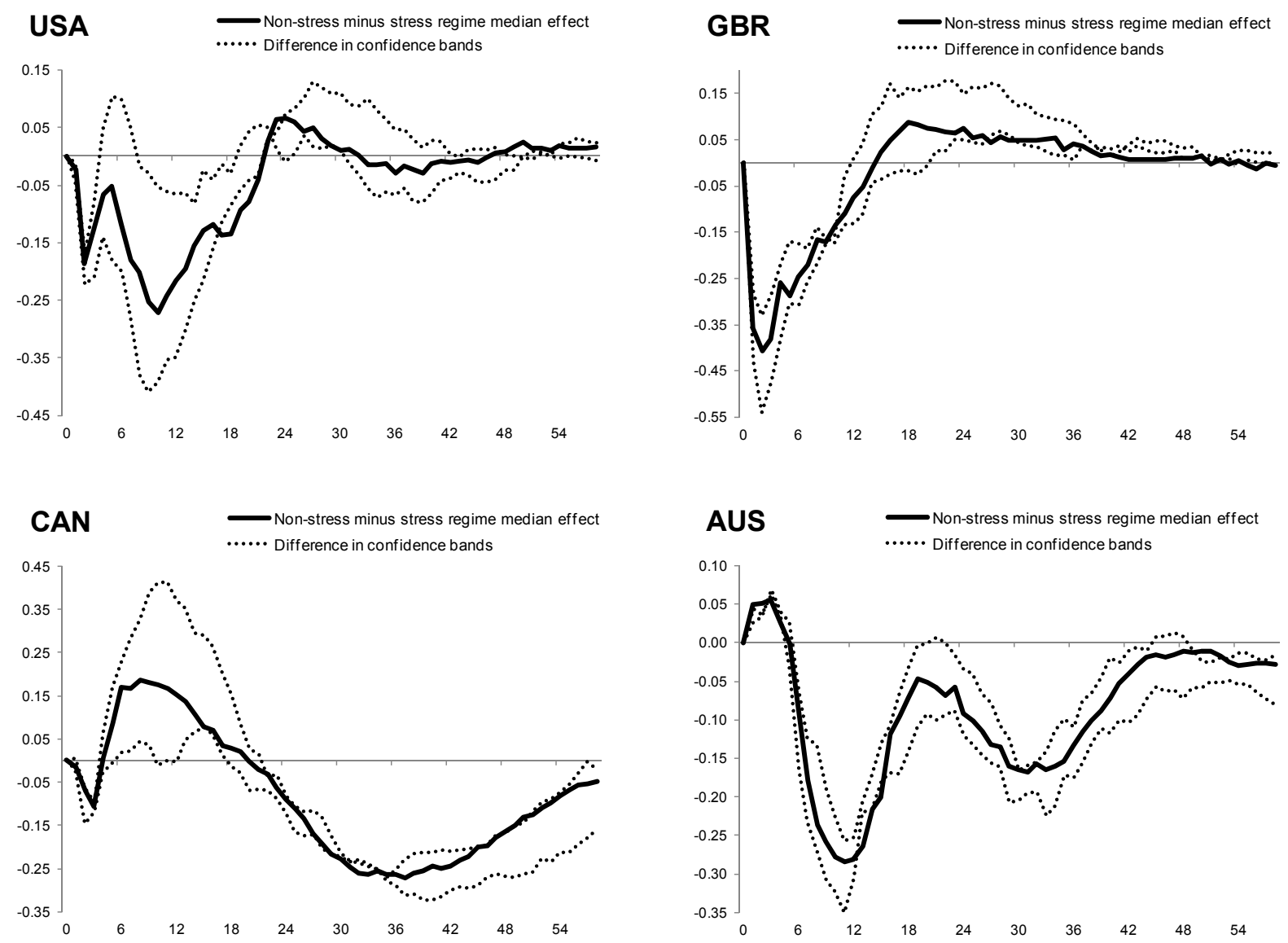

Source. Author's calculations.

Note: The panel shows differences between impulse responses across regimes from the TVAR model to a shock of 100 bps to the yield curve slope, which is equivalent to a monetary policy tightening via an interest rate hike. The horizontal axis measures the months after the shock.

The above results suggest that an stressed financial sector impairs the transmission mechanism of monetary policy shocks and prevents these shocks to deteriorate output growth further. For the same reason, a symmetric monetary policy shock that steepens the yield curve would fall short in helping recover output under financial distress. One could think as an example about the euro area recently, the United States as described in Peek and Rosengren (2013) or in many advanced economies (Bech et al., 2014). As a result, the TVAR model shows that if monetary policy is used when the financial system is under stress, the stimulus should be larger to obtain the same effects on output growth of a smaller shock under non-stress conditions.

\section{Monetary Policy and Financial Stress}

Monetary policy does "get in the cracks" and has different effects on financial stress across regimes. Figure 4 presents the estimated impulse response of ADD to a one-time shock of 
100 bps in the yield curve slope in non-stress and stress regimes and their corresponding 16 th and 84 th percentiles.

As expected, a flattened slope, reflecting a tightening of monetary policy, deteriorates financial conditions, and induces financial stress across countries. In contrast to the findings for output growth, the effect is stronger during stress regimes and it also reaches its peak faster and lasts longer. In other words, monetary policy has stronger and relatively faster effects in stabilizing the financial system when the financial system is already under stress. Conversely, a flatter slope adds more stress to the financial system.

This result has important implications for the option to "lean against the wind", as it shows that the effect of monetary policy easing under financial stress is comparatively smaller on the financial system and more consequential than it is to restore economic growth. Symmetrically, in normal times, monetary policy tightening would create more costs in terms of economic growth if the target is to discipline the financial sector.

These findings also draw attention to complementary roles of monetary and macroprudential policies in addressing financial stress and containing financial stability vulnerabilities. In particular, in line with findings in IMF (2015), macroprudential policy remains a key element of the defense against financial instability while monetary policy shows potential to address effectively financial stress when it materializes.

Differences across regimes are easier to identify for ADD than for output growth. Figures 5 and 6 provide additional evidence. In particular, the positive differences in Figure 5 indicate that the 100 bps shock to monetary policy has more repercussions under stress in all countries and that the effect may last longer than for output growth despite being small after the peak. 
Figure 4. Impulse Response Functions-

Impact of a 100 bps Monetary Policy Shock on Average Distance-to-Default
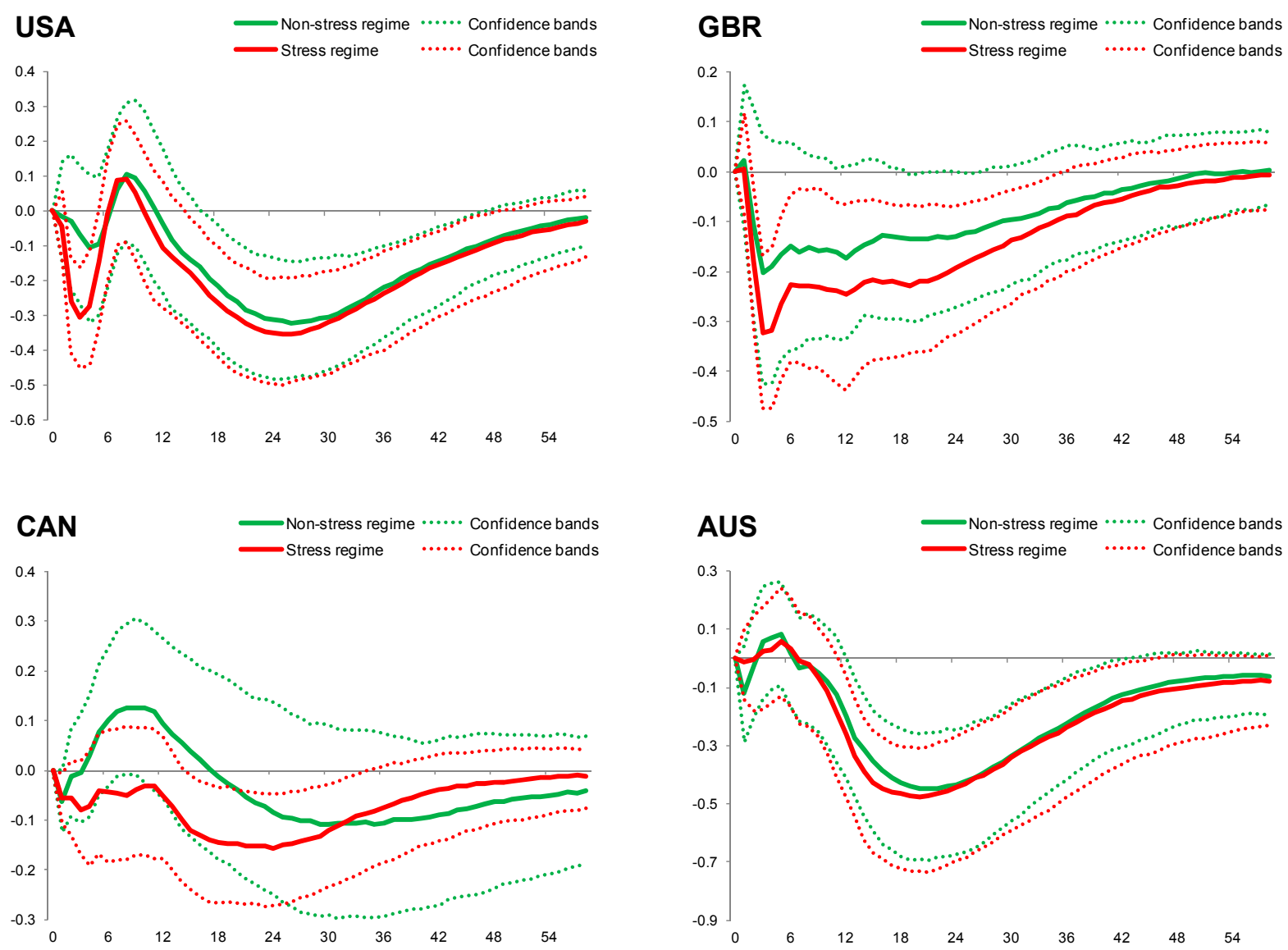

Source. Author's calculations.

Note: The panel shows impulse response functions according to the TVAR model described above to a shock of $100 \mathrm{bps}$ to the yield curve slope, which is equivalent to a monetary policy tightening via an interest rate hike. Green (red) lines and confidence bands correspond to non-stress (stress) regimes and are measured in the vertical axis in number of standard deviations of ADD to the distress barrier, which are the specific units of this measure. The horizontal axis measures the months after the shock. 
Figure 5. Differences Across RegimesDifference in Impact of a 100 bps Monetary Policy Shock on ADD
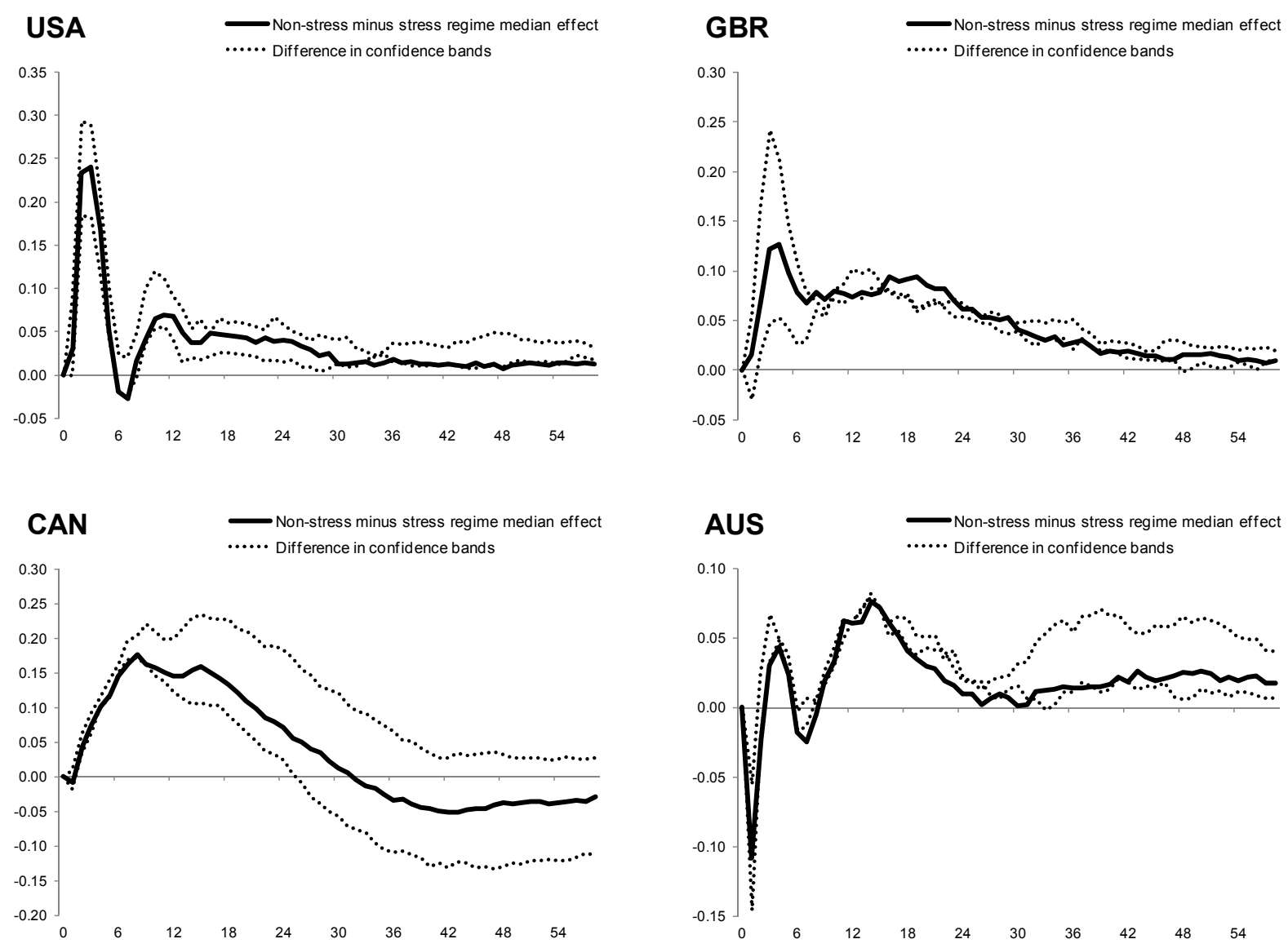

Source. Author's calculations.

Note: The panel shows differences between impulse responses across regimes from the TVAR model to a shock of 100 bps to the yield curve slope, which is equivalent to a monetary policy tightening via an interest rate hike. The horizontal axis measures the months after the shock.

Figure 6 shows the potential effects of monetary policy shocks across regimes. Sufficiently strong monetary policy tightening may raise the probabilities of default to levels that are close to commonly known systemic events. Figure 6 presents the maximum possible change in estimated median ADD in non-stress and stress regimes after a one-time shock of $100 \mathrm{bps}$ in the yield curve slope.

At the peak of non-stress times, the shock to ADD is not very significant. In stress times, ADD drops however significantly more and, due to nonlinearities, the corresponding probabilities of default rise close to levels only seen at the height of events like the 1987 crash, the 1990 recession and Iraq war, the Russian crisis/LTCM, the dot-com bubble or the Bear Stearns failure. 
Figure 6. Maximum Impact of a 100 bps Monetary Policy Shock on MedianAverage Distance-to-Default Across Regimes
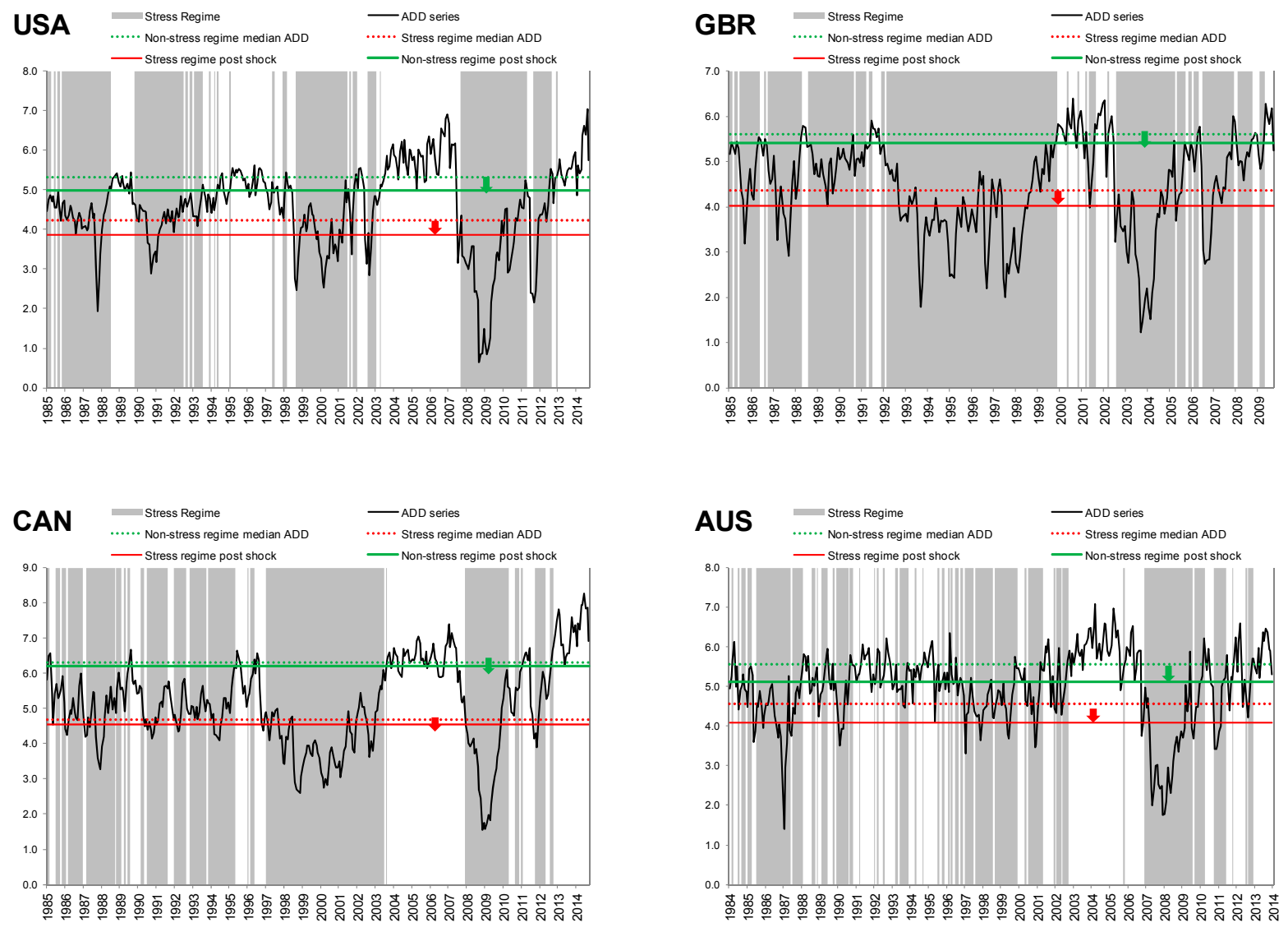

Source. Author's calculations.

Note: The panel shows the ADD series over time across stress regimes (grey shaded areas) according to the TVAR model. The green (red) dotted line represents the median ADD during the non-stress (stress regime) The solid green (red) line shows the ADD level at the peak effect during non-stress (stress) times of the shock of $100 \mathrm{bps}$ to the yield curve slope, which is equivalent to a monetary policy tightening via an interest rate hike.

\section{Robustness Checks}

\section{A. Alternative FSI Thresholds}

As robustness checks, I ran the TVAR models using the FSI reported by the IMF as thresholds. Appendix III includes figures of corresponding regimes, IRF and their differences. In this case, stress occurs when the FSI increase.

Appendix III, Figure 7 shows the regimes delineated by the FSI series. The FSI stress regimes closely overlap ADD regimes but are narrower, placing more weight in the estimation to the priors than the baseline model. As a result, they generally identify more severe stress episodes than ADD and the coincidence across countries is therefore reduced 
mainly to global stress episodes. These regimes have in general less coincidence with recession dates with the exception of the United States.

Appendix III, Figures 8 and 9 show impulse response functions and differences across regimes for shocks to output growth and to the FSI series, respectively. The main results are broadly consistent with those obtained when ADD was used as threshold variable, especially for output growth. Monetary policy shocks exert a stronger effect on output growth when the financial system is sound and the transmission mechanism works. The same shock has smaller impact on financial conditions in the short run.

\section{B. Testing Regimes}

This section stresses the nonlinearity assumption of the TVAR model and its relative performance across countries using the Deviance Information Criterion (DIC) by Spiegelhalter (2002). ${ }^{21}$ The DIC statistic is a model selection criterion and tests whether financial regimes are in fact meaningful as the TVAR policy insights and better fit and performance gains could be offset by its complexity.

The DIC test is computed using the mean likelihood of the model and the total number of effective parameters to penalize for complexity. A lower value of the statistic indicates better performance against an alternative model. Three model specifications are considered, namely: (1) a BVAR, ${ }^{22}$ which allows for only linear interactions in the system due to the absence of financial stress regimes; (2) the baseline TVAR with ADD as threshold variable; and (3) a TVAR with FSI series as threshold.

Results of the test are reported in Table 1. For all countries, the linear model with no regimes is a poor performer compared to any model with financial stress regimes determined by ADD. As a result, the higher complexity of the TVAR model is justified to achieve a better representation of the system's dynamics and specially to derive important policy implications about the interaction between financial stress and monetary policy.

TVAR models' results with different thresholds were shown to be consistent in the previous section. The DIC-based comparison shows that ADD series are indeed a reasonable choice to define financial conditions and establish the financial stress regimes in general.

\footnotetext{
${ }^{21}$ Non-Bayesian TVAR models reviewed in Section II rely on sup-Wald statistics for nonlinearity tests.

${ }^{22}$ The BVAR specification shares all priors and methodological assumptions of the TVAR model described in Section III and Appendix I.
} 
Table 1. Deviance Information Criterion

\begin{tabular}{ccccccc}
\hline \multirow{2}{*}{ Model } & Type & Threshold & USA & GBR & CAN & AUS \\
\hline 1 & BVAR & - & -1127.8 & -482.0 & -317.0 & -1719.0 \\
2 & TVAR & ADD & -2011.4 & -706.7 & -618.3 & -1997.6 \\
3 & TVAR & FSI & 168.7 & -155.5 & 521.7 & -1147.0 \\
\hline
\end{tabular}

Source. Author's calculations.

Note: The table reports the Deviance Information Criterion of Spiegelhalter et al. (2002) for three model specifications. Model 1 assumes no regimes. Models 2 and 3 are nonlinear and assume regimes driven by financial stress. Financial stress is determined in Model 2 by Average Distance-to-Default and in Model 3 by Financial Stress Index series (see Section V.A). In bold are highlighted the models with best performance.

\section{Conclusions}

This paper finds that monetary policy and stressed financial conditions have a nonlinear relationship. The findings suggest that the effects of monetary policy shocks on output are stronger when the financial system is sound. This may reflect the proper functioning of the transmission mechanism through the supply of credit and overall conditions in the financial markets. The results also suggest that a stressed financial sector impairs the transmission mechanism and that the effects of an expansionary monetary policy shock under those regimes would not be too effective to stabilize output.

The findings show that direct effect of a monetary policy shock on financial conditions is considerably larger when the financial system is under stress. This suggests that expansionary monetary policy can really "get into the cracks" and help rebuild resilience of the financial system when it is needed. However, a tightening of monetary of the same magnitude is less effective in containing vulnerabilities in normal times. 


\section{APPENDiX I. BAYESIAN THREShOLd VECTOR AUTOREgRESSION MOdEL}

Following Alessandri and Mumtaz (2017) and their notation, the model specification is the following:

$$
Z_{t}=\left[c_{1}+\sum_{j=1}^{P} B_{1 j} Z_{t-j}+\Omega_{1 t}^{1 / 2} e_{t}\right]\left(1-\tilde{S}_{t}\right)+\left[c_{2}+\sum_{j=1}^{P} B_{2 j} Z_{t-j}+\Omega_{2 t}^{1 / 2} e_{t}\right] \tilde{S}_{t}
$$

Where $e_{i t} \sim N(0,1)$ and $\tilde{S}_{t}=1 \Leftrightarrow F S I_{t-d} \leq F S I^{*}$ for $\mathrm{t}=1, \ldots T$.

$Z_{t}(N x 1)$ is the is the vector that contains the four endogenous variables: Output growth $\left(y_{t}\right)$; Inflation rate, $(\pi t)$; Financial stress index, measured by either a Financial Stress Index $\left(F S I_{t}\right)$ or Average Distance-to-default series $\left(A D D_{t}\right)$ series, and the yield curve slope (slope $) . c_{i}, B_{i}$ and $\Omega_{i t}$ are the parameters for the two regimes $i=1,2$. Following similar applications in the literature, the lag length $P$ is set to 13 .

The regime is set by level of the stress indicator, $F S I_{t-d}$, relative to a threshhold $F S I^{*}$ that determines stress and non-stress periods with the delay parameter $d$ that will be jointly estimated. This threshold splits the sample into a sub-sample for each regime and the maximnum delay has been set to range between 1 and 12 .

The prior used is a natural conjucate prior as described in Banbura el al. (2010) for both regimes it uses the following dummy observations:

$$
Y_{D, 1}=\left(\begin{array}{c}
\frac{\operatorname{diag}\left(\gamma_{1} \sigma_{1 \ldots} \gamma_{N} \sigma_{N}\right)}{\tau} \\
0_{N x(P-1) x N} \\
\ldots \ldots \ldots \ldots \\
\operatorname{diag}\left(\sigma_{1} \sigma_{N}\right) \\
\ldots \ldots \ldots \ldots \\
0_{1 \times N} \ldots
\end{array}\right), \text { and } X_{D, 1}=\left(\begin{array}{cc}
\frac{J_{P} \otimes \emptyset \operatorname{diag}\left(\sigma_{1 \ldots} \sigma_{N}\right)}{\tau} & 0_{N P x 1} \\
0_{N x N P} & 0_{N x 1} \\
\ldots \ldots \ldots \ldots & \ldots \ldots \ldots \ldots \\
0_{1 x N P} & c
\end{array}\right)
$$

Where $\gamma_{1}$ to $\gamma_{N}$ refer to the prior mean for the coefficients of the first lag. They are obtained from OLS estimations of the coefficients of an AR(1) regression for each endogenous variable using a 60 -month training sample. $\sigma_{i}$ are scaling factors obtained as the standard deviation of error terms of the preliminary AR(1) regressions. $\tau$ is the tightness of the prior on the VAR coefficients and has been set to $0.1 \mathrm{c}$ is the tightness of the prior on the constant, set to 1 .

In addition, the prior for the sum of lagged dependent variables is introduced by the following dummies:

$$
Y_{D, 2}=\frac{\operatorname{diag}\left(\gamma_{1} \mu_{1 \ldots} \gamma_{N} \mu_{N}\right)}{\lambda} \text {, and } X_{D, 2}=\frac{1_{1 x P} \otimes \emptyset \operatorname{diag}\left(\gamma_{1} \mu_{1 \ldots} \gamma_{N} \mu_{N}\right)}{\lambda}
$$

$\mu_{i}$ are the sample means of endogenous variables computed in the training sample. This prior is set as: $\lambda=10 \tau=1$. 
The conditional posteriors distributions for the VAR parameters $B$ and $\Omega$ under the natural conjugate prior are known analytically and are defined as follows:

$$
\begin{gathered}
G(B \backslash \Omega) \sim N\left(B^{*}, \Omega \otimes\left(X^{* \prime} X^{*}\right)^{-1}\right) \\
G(\Omega \backslash B) \sim I W\left(S^{*}, \mathrm{~T}^{*}\right)
\end{gathered}
$$

Where $B^{*}=\left(X^{* \prime} X^{*}\right)^{-1}\left(X^{* \prime} Y^{*}\right)$ and $S^{*}=\left(Y^{*}-X^{*} \widetilde{\mathrm{B}}\right)^{\prime}\left(Y^{*}-X^{*} \widetilde{\mathrm{B}}\right)$

With $Y^{*}=\left[Y ; Y_{D, 1} ; Y_{D, 2}\right],\left[X ; X_{D, 1} ; X_{D, 2}\right] ; \widetilde{\mathrm{B}}$ are reshaped draws of the coefficients and $T^{*}$ is the number of rows in $Y^{*}$.

The method to draw the posterior distribution of the parameters is Gibbs sampling and Metropolis Hastings is employed to sample the threshold value $F S I^{*}$ with an acceptance rate between 20-40 percent. The model uses 20.500 iterations and the first 20.000 are discarded. 


\section{APPENDIX II. DATA SOURCES AND DEFINITIONS}

\section{Appendix Table 1. Macrofinancial Data}

\begin{tabular}{|c|c|c|c|c|c|c|}
\hline \multirow[b]{2}{*}{ Country } & \multirow[b]{2}{*}{ Sample } & \multicolumn{5}{|c|}{ Source, Identifier } \\
\hline & & Output & Inflation & $\begin{array}{l}\text { Long-Term } \\
\text { Interest Rate }\end{array}$ & $\begin{array}{l}\text { Short-Term } \\
\text { Interest Rate }\end{array}$ & $\mathrm{FSI}$ \\
\hline USA & Jan $1984-O c t 2014$ & $\begin{array}{l}\text { FRED, } \\
\text { INDPRO }\end{array}$ & $\begin{array}{l}\text { FRED, } \\
\text { CPIAUCSL }\end{array}$ & $\begin{array}{l}\text { FRED, } \\
\text { GS10 }\end{array}$ & $\begin{array}{l}\text { FRED } \\
\text { TB3MS }\end{array}$ & $\begin{array}{l}\text { IMF, } \\
111 \mathrm{FSI}\end{array}$ \\
\hline GBR & Jan 1989-Oct 2014 & $\begin{array}{l}\text { ONS, } \\
\text { D7BT }\end{array}$ & $\begin{array}{l}\text { ONS, } \\
\text { K222 }\end{array}$ & $\begin{array}{l}\text { Bloomberg, } \\
\text { GUKG10 Index }\end{array}$ & $\begin{array}{l}\text { Bank of England, } \\
\text { IUMAJNB }\end{array}$ & $\begin{array}{l}\text { IMF, } \\
\text { 112FSI.M }\end{array}$ \\
\hline CAN & Jan 1984-Oct 2014 & $\begin{array}{l}\text { FRED, } \\
\text { CANPROINDMISME }\end{array}$ & $\begin{array}{l}\text { Datastream, } \\
\text { ICNCONPRCF }\end{array}$ & $\begin{array}{l}\text { Datastream, } \\
\text { CNGBOND. }\end{array}$ & $\begin{array}{l}\text { Datastream, } \\
\text { CNGBILL3 }\end{array}$ & $\begin{array}{l}\text { IMF, } \\
\text { 156FSI.M }\end{array}$ \\
\hline AUS & Sep 1983-Oct 2014 & $\begin{array}{l}\text { Datastream, } \\
\text { AUCIND..G }\end{array}$ & $\begin{array}{l}\text { Datastream, } \\
\text { AUCCPI..E }\end{array}$ & $\begin{array}{l}\text { Bloomberg, } \\
\text { GACGB10 } \\
\text { Index }\end{array}$ & $\begin{array}{l}\text { Bloomberg, } \\
\text { GACGB2 Index }\end{array}$ & $\begin{array}{l}\text { IMF, } \\
\text { 193FSI.M }\end{array}$ \\
\hline
\end{tabular}

Source: Author's calculations. 


\begin{tabular}{|c|c|c|c|c|c|}
\hline \multicolumn{6}{|c|}{ Appendix Table 2. Financial Companies' Names and ISIN Codes } \\
\hline \multicolumn{2}{|l|}{ USA } & \multirow[b]{2}{*}{ Bank of Hawaii } & \multirow[b]{2}{*}{ US0625401098 } & \multirow[b]{2}{*}{ BFC Financial } & \multirow[b]{2}{*}{ US0553842008 } \\
\hline JP Morgan Chase & US46625H1005 & & & & \\
\hline Bank of America & US0605051046 & Bancorpsouth & US0596921033 & Westfield Finl. & US96008P1049 \\
\hline Citigroup & US1729674242 & International Bcsh. & US4590441030 & Fox Chase Bancorp & US35137T1088 \\
\hline Wells Fargo & US9497461015 & Trustmark & US8984021027 & First Financial Nw. & US32022K1025 \\
\hline US Bancorp & US9029733048 & Sterling Finl. & US8593193035 & Bbx Capital Class A & US05540P1003 \\
\hline PNC Finl.Svs.Gp. & US6934751057 & Old National Bancorp & US6800331075 & Bank One & US06423A1034 \\
\hline BB\&T & US0549371070 & Flagstar Bancorp & US3379307057 & Metlife & US59156R1086 \\
\hline Suntrust Banks & US8679141031 & United Bankshares & US9099071071 & Prudential Finl. & US7443201022 \\
\hline SLM & US78442P1066 & Capitalsource & US14055X1028 & American Intl.Gp. & US0268747849 \\
\hline Fifth Third Bancorp & US3167731005 & Nat.Penn Bancshares & US6371381087 & Berkshire Hathaway & US0846701086 \\
\hline Regions Finl. & US7591EP1005 & First Midwest Banc. & US3208671046 & Hartford Finl.Svs.Gp. & US4165151048 \\
\hline Keycorp & US4932671088 & Northwest Bancshares & US6673401039 & Lincoln National & US5341871094 \\
\hline M\&T Bank & US55261F1049 & Glacier Bancorp & US37637Q1058 & Principal Finl.Gp. & US74251V1026 \\
\hline Comerica & US2003401070 & Provident Finl.Svs. & US74386T1051 & Allstate & US0200021014 \\
\hline Huntington Bcsh. & US4461501045 & Berkshire Hills Bancorp & US0846801076 & Aflac & US0010551028 \\
\hline Zions Bancorp. & US9897011071 & Brookline Bancorp & US11373M1071 & Genworth Financial & US37247D1063 \\
\hline New York Com. Banc. & US6494451031 & Westamerica Bancorp. & US9570901036 & Travelers Cos. & US89417E1091 \\
\hline Hudson City Banc. & US4436831071 & Flushing Financial & US3438731057 & Loews & US5404241086 \\
\hline First Niagara Finl.Gp. & US33582V1089 & Beneficial Mutual Banc. & US08173R1041 & Protective Life & US7436741034 \\
\hline Peoples United Financial & US7127041058 & Wsfs Financial & US9293281021 & Cna Financial & US1261171003 \\
\hline City National & US1785661059 & Bofi Holding & US05566U1088 & Unum Group & US91529Y1064 \\
\hline BOK Finl. & US05561Q2012 & Dime Cmty.Bcsh. & US2539221083 & Chubb & US1712321017 \\
\hline SVB Financial Group & US78486Q1013 & Banc Of California & US05990K1060 & American Finl.Gp.Ohio & US0259321042 \\
\hline Synovus Financial & US87161C5013 & Viewpoint Financial Gp. & US92672A1016 & Reinsurance Gp Of Am. & US7593516047 \\
\hline Cullen Fo.Bankers & US2298991090 & Kearny Financial & US4871691048 & Cno Financial Group & US12621E1038 \\
\hline Associated Banc-Corp & US0454871056 & Oritani Financial & US68633D1037 & Ambac Financial Group & US0231391089 \\
\hline Firstmerit & US3379151026 & Homestreet & US43785V1026 & Progressive Ohio & US7433151039 \\
\hline First Horizon National & US3205171057 & Northfield Bancorp Del. & US66611T1088 & Assurant & US04621X1081 \\
\hline Commerce Bcsh. & US2005251036 & Meridian Bancorp & US58958U1034 & Markel & US5705351048 \\
\hline First Ctzn.Bcsh.A & US31946M1036 & United Fin. Bancorp & US91030T1097 & Amer.Nat.In. & US0285911055 \\
\hline Webster Financial & US9478901096 & $\begin{array}{l}\text { Bank Mut. } \\
\text { United Financial }\end{array}$ & US0637501034 & Alleghany & US0171751003 \\
\hline Hancock Holding & US4101201097 & Bancorp & US9103041045 & Phoenix & US71902E6041 \\
\hline Prosperity Bcsh. & US7436061052 & Oceanfirst Finl. & US6752341080 & Stancorp Finl.Gp. & US8528911006 \\
\hline Susquehanna Bcsh. & US8690991018 & First Defiance Finl. & US32006W1062 & W R Berkley & US0844231029 \\
\hline TCF Financial & US8722751026 & Hometrust Bancshares & US4378721041 & Torchmark & US8910271043 \\
\hline Fulton Financial & US3602711000 & Waterstone Financial & US94188P1012 & Cincinnati Finl. & US1720621010 \\
\hline UMB Financial & US9027881088 & ESB Finl. & US26884F1021 & Erie Indemnity & US29530P1021 \\
\hline Valley National Bancorp & US9197941076 & Pac.Premier Banc. & US69478X1054 & Old Republic Intl. & US6802231042 \\
\hline Astoria Finl. & US0462651045 & Territorial Bancorp & US88145X1081 & Marsh \& Mclennan & US5717481023 \\
\hline Investors Bancorp & US46146L1017 & Isabella Bank & US4642141059 & MBIA & US55262C1009 \\
\hline Bankunited & US06652K1034 & Bankfinancial & US06643P1049 & White Mountains In.Gp. & BMG9618E1075 \\
\hline
\end{tabular}




\section{Appendix Table 2. Financial Companies' Names and ISIN Codes (continued)}

\begin{tabular}{|c|c|c|c|c|c|}
\hline \multicolumn{2}{|l|}{ USA (Continued) } & \multirow{2}{*}{$\begin{array}{l}\text { Standard Life } \\
\text { Old Mutual }\end{array}$} & \multirow{2}{*}{$\begin{array}{l}\text { GB00B16KPT44 } \\
\text { GB00B77J0862 }\end{array}$} & \multirow{2}{*}{$\begin{array}{l}\text { Indl.All.In.\& Finl.Svs. } \\
\text { Fairfax Finl.Hdg. }\end{array}$} & \multirow{2}{*}{$\begin{array}{l}\text { CA4558711038 } \\
\text { CA3039011026 }\end{array}$} \\
\hline Hanover Insurance Group & US4108671052 & & & & \\
\hline HCC Insurance Hdg. & US4041321021 & St. James's Place & GB0007669376 & Intact Financial & CA45823T1066 \\
\hline Hilltop Holdings & US4327481010 & Aon & GB00B5BT0K07 & E-L Financial & CA2685751075 \\
\hline Kemper & US4884011002 & RSA Insurance Group & GB00BKKMKR23 & Northbridge Finl. & CA6638021064 \\
\hline Arthur J Gallagher & US3635761097 & Amlin & GB00B2988H17 & & \\
\hline Selective In.Gp. & US8163001071 & Admiral Group & GB00B02J6398 & \multicolumn{2}{|l|}{ AUSTRALIA } \\
\hline Proassurance & US74267C1062 & Lancashire Holdings & BMG5361W1047 & National Australia Bank & AU000000NAB4 \\
\hline One Beacon In.Gp & BMG677421098 & Jardine Lloyd Thompson & GB0005203376 & Commonwealth Bank & AU000000CBA7 \\
\hline Mercury General & US5894001008 & & & Australia \& Nz Bank & AU000000ANZ3 \\
\hline Brown \& Brown & US1152361010 & \multicolumn{2}{|l|}{ CANADA } & Westpac Banking Corp & AU000000WBC1 \\
\hline RLI & US7496071074 & Toronto-Dominion Bank & CA8911605092 & Bendigo And Adelaide & AU000000BEN6 \\
\hline State Auto Finl. & US8557071052 & Royal Bank Of Canada & CA7800871021 & Bank Of Queensland & AU000000BOQ8 \\
\hline & & Bank of Nova Scotia & CA0641491075 & St. George Bank Ltd & AU000000SGB0 \\
\hline \multicolumn{2}{|l|}{ UNITED KINGDOM } & Bank Of Montreal & CA0636711016 & AMP Limited & AU000000AMP6 \\
\hline HSBC & GB0005405286 & CIBC & CA1360691010 & QBE Insurance Group & AU000000QBE9 \\
\hline Barclays & GB0031348658 & National Bank Of Canada & CA6330671034 & Insurance Australia & AU000000IAG3 \\
\hline RBS & GB00B7T77214 & Canadian Western Bank & CA13677F1018 & Challenger Fin'l Svc & AU000000CGF5 \\
\hline Lloyds Banking Group & GB0008706128 & Manulife Financial & CA56501R1064 & Axa Asia Pacific & AU000000AXA5 \\
\hline Standard Chartered & GB0004082847 & Power Corporation of Canada & CA7392391016 & Promina Group & AU000000PMN9 \\
\hline Legal \& General & GB0005603997 & Power Financial Corp. & CA73927C1005 & & \\
\hline Prudential & GB0007099541 & Great West Lifeco & CA39138C1068 & & \\
\hline Aviva & GB0002162385 & Sun Life Finl. & CA8667961053 & & \\
\hline
\end{tabular}

Source. Bloomberg.

Note. The ADD series are computed using the individual DD series of the institutions listed in the table. The list of active and defunct financial companies was obtained from the constituents of the Bloomberg BWORLD Index since the start of its sample. I used the Industry Classification Benchmark (ICB) to select banks and insurance institutions. With their respective ISIN codes, I then obtained information about equity prices, market capitalization, total assets, short-term liabilities, and equity from Thomson Reuters/Worldscope. 
APPENDIX III. SUPPLEMENTARY FIGURES

Appendix Figure 7. Financial Stress Regimes Determined by Financial Stress Index Series

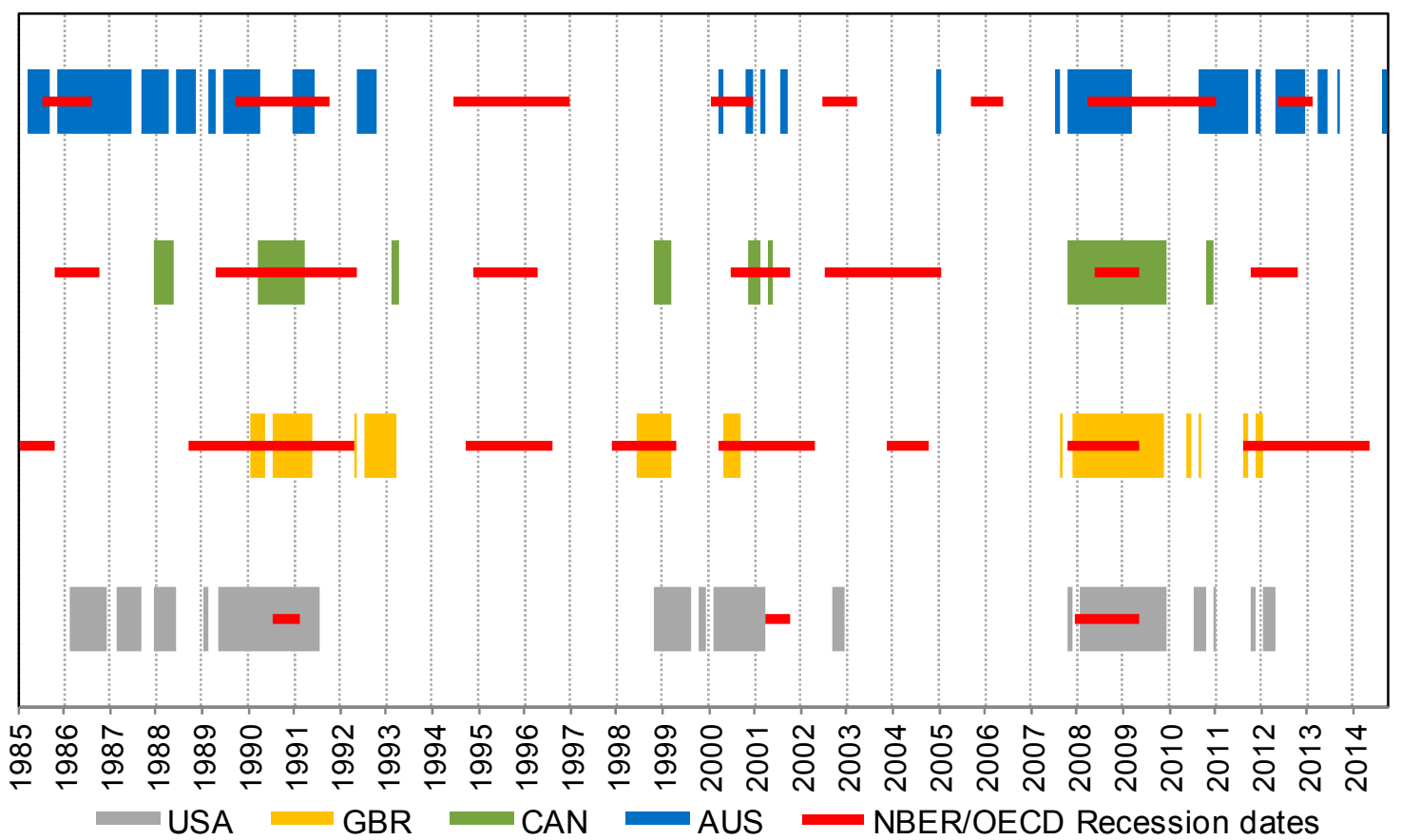

Source. Authors' calculations and FRED.

Note: The colored shaded areas indicate periods of stress determined by the TVAR model using FSI series as thresholds. The data sample for each country starts at the end of shaded gray areas. Based on data from January 1984 to October 2014 for USA, CAN, and AUS and from January 1989 to October 2014 for GBR. 


\section{Appendix Figure 8. Impulse Response Functions- Impact of a 100 bps Monetary Policy Tightening on Output Growth Threshold Variable: FSI}
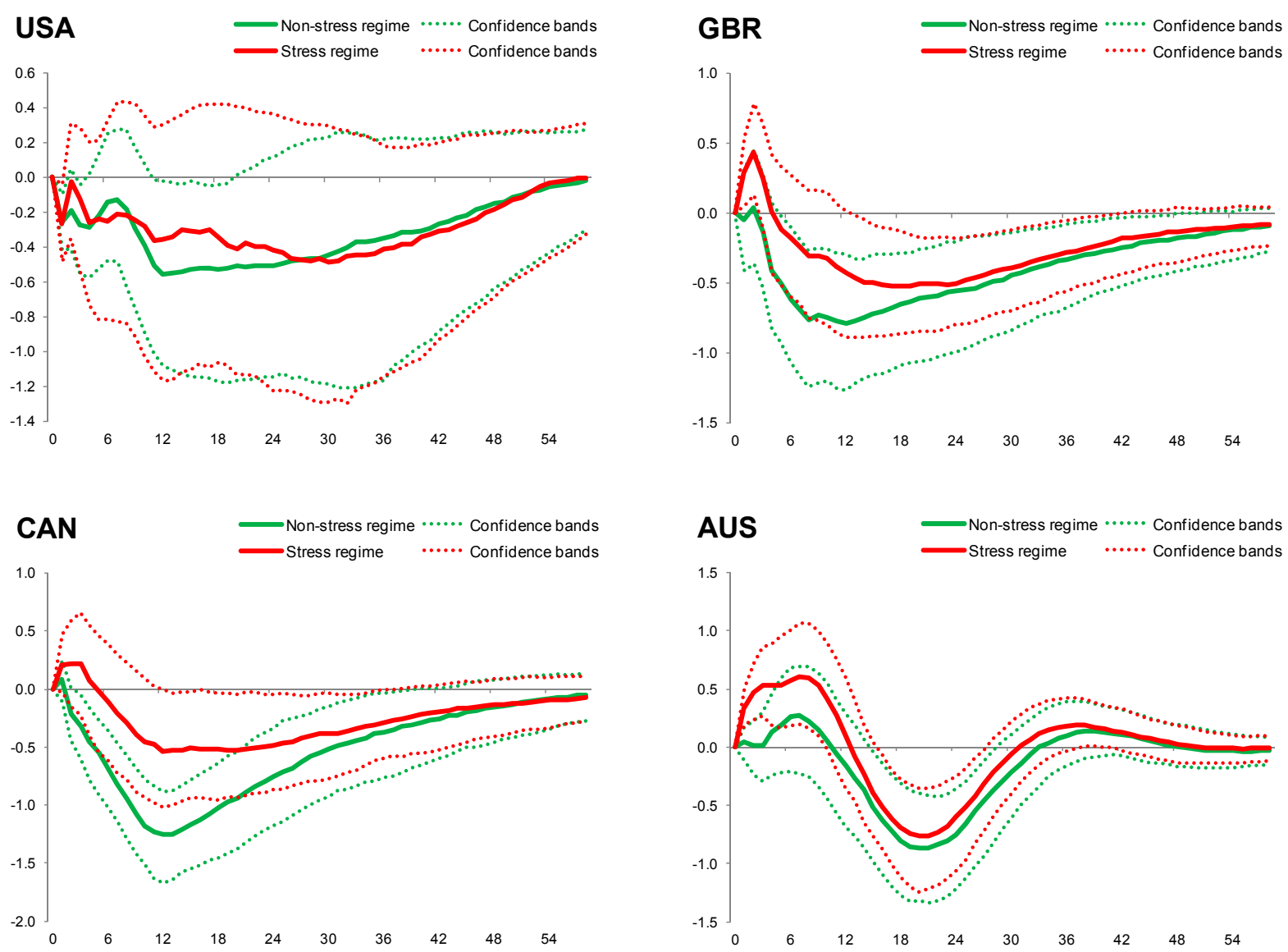

Source. Author's calculations.

Note: The panel shows impulse response functions according to the TVAR model described above to a negative shock of 100 bps to the yield curve slope, which is equivalent to a monetary policy tightening via an interest rate hike. Green (red) lines and confidence bands correspond to non-stress (stress) regimes and are measured in the vertical axis in percentage points. The horizontal axis measures the months after the shock. 


\section{Appendix Figure 9. Impulse Response Functions Impact of a 100 bps Monetary Policy Shock on FSI}
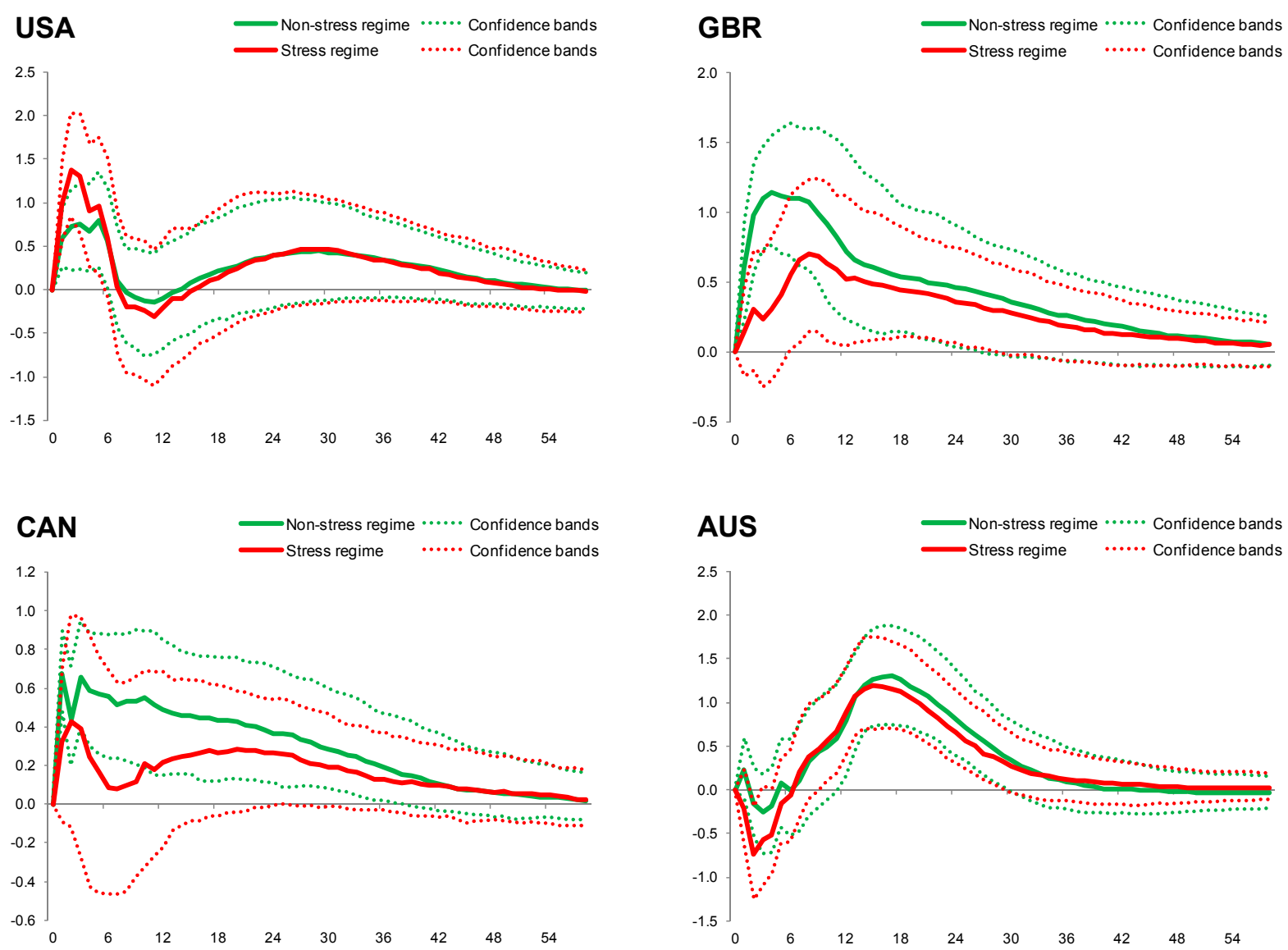

Source. Author's calculations.

Note: The panel shows impulse response functions according to the TVAR model described above to a negative shock of $100 \mathrm{bps}$ to the yield curve slope, which is equivalent to a monetary policy tightening via an interest rate hike. Green (red) lines and confidence bands correspond to non-stress (stress) regimes and are measured in the vertical axis in number FSI units, which are the specific of this measure. A positive value denotes an increase in financial stress. The horizontal axis measures the months after the shock. 


\section{REFERENCES}

Adrian, Tobias, Arturo Estrella and Hyun Song Shin, 2010, "Monetary Cycles, Financial Cycles, and the Business Cycle," Staff Reports 421, Federal Reserve Bank of New York.

Adrian, Tobias and Nellie Liang, 2015, "Monetary Policy, Financial Conditions, and Financial Stability,” Federal Reserve Bank of New York Staff Reports, No. 690.

Alessandri, Piergiorgio and Haroon Mumtaz, 2014b, "Financial Regimes and Uncertainty Shocks," Working Papers 729, Queen Mary University of London, School of Economics and Finance.

Alessandri, Piergiorgio and Haroon Mumtaz, 2017, "Financial Indicators and Density Forecasts for U.S. Output and Inflation," Review of Economic Dynamics, Vol. 14, pp. 66-78.

Alessandri, Piergiorgio and Benjamin Nelson, 2015, "Simple Banking: Profitability and the Yield Curve," Journal of Money, Credit and Banking, Vol. 47, No. 1, pp. 1431-75.

Angeloni, Ignazio, Ester Faia and Marco Lo Duca, 2015, "Monetary Policy and Risk Taking," Journal of Economic Dynamics and Control, Vol. 52, No. C, pp 285-307.

Atanasova Christina, 2003, "Credit Market Imperfections and Business Cycle Dynamics: A Nonlinear Approach," Studies in Nonlinear Dynamics \& Econometrics, Vol. 7, No. 4, pp. 1-22.

Avdjiev, Stefan and Zheng Zeng, 2014, "Credit Growth, Monetary Policy, and Economic Activity in a Three-Regime TVAR Model," Applied Economics, Vol. 46, No. 24, pp. 2936-2951.

Balke, Nathan, 2000, "Credit and Economic Activity: Credit Regimes and Nonlinear Propagation of Shocks," Review of Economics and Statistics, Vol. 82, No. 2, pp. 344 349.

Banbura, Marta, Domenico Giannone and Lucrezia Reichlin, 2010, "Large Bayesian Vector Auto Regressions,” Journal of Applied Econometrics, Vol. 25, No. 1, pp. 71-92.

Bech, Morten, Leonardo Gambacorta and Enisse Kharroubi, 2014, "Monetary Policy in a Downturn: are Financial Crises Special?” International Finance, Vol. 17, No. 1, pp. 99-119.

Baumeister, Christiane and Luca Benati, 2013, "Unconventional Monetary Policy and the Great Recession: Estimating the Macroeconomic Effects of a Spread Compression at the Zero Lower Bound," International Journal of Central Banking, Vol. 9, No. 2, pp. 165-212. 
Bernanke, Ben and Mark Gertler, 1989, "Agency Costs, Net Worth, and Business Fluctuations," American Economic Review, Vol. 79, No. 1, pp. 14-31.

Bernanke, Ben, Mark Gertler and Simon Gilchrist, 1996, "The Financial Accelerator and the Flight to Quality," Review of Economics and Statistics, Vol. 78, No. 1, pp. 1-15.

Blinder, Alan, 1987, “Credit Rationing and Effective Supply Failures,” Economic Journal, Vol. 97, No. 386, pp. 327-352.

Borio, Claudio and Haibin Zhu, 2012, "Capital Regulation, Risk-Taking and Monetary Policy: A Missing Link in the Transmission Mechanism?” Journal of Financial Stability, Vol. 8, No. 4, pp. 236-251.

Borio, Claudio, Leonardo Gambacorta and Boris Hofmann, 2015, “The Influence of Monetary Policy on Bank Profitability,” BIS Working Papers 514.

Buch, Claudia, Sandra Eickmeier and Esteban Prieto, 2014, "In Search for Yield? SurveyBased Evidence on Bank Risk Taking," Journal of Economic Dynamics and Control, Vol. 43, No. C, pp. 12-30.

Calza, Alessandro and João Sousa, 2006, "Output and Inflation Responses to Credit Shocks: are There Threshold Effects in the Euro Area?" Studies in Nonlinear Dynamics \& Econometrics, Vol. 10, No. 2, pages 1-21.

Cardarelli, Roberto, Selim Elekdag and Subir Lall, 2011, "Financial Stress and Economic Contractions," Journal of Financial Stability, Vol. 7, No. 2, pp. 78-97.

Ciccarelli, Matteo, Angela Maddaloni and José Luis Peydró, 2015, "Trusting the Bankers: A New Look at the Credit Channel of Monetary Policy, " Review of Economic Dynamics, Vol. 18, No. 4, pp. 979-1002.

Crosbie, Peter and Jeff Bohn, 2003, "Modeling Default Risk. Modelling Methodology," Whitepaper, KMV Corporation.

Eickmeier, Sandra, Massimiliano Marcellino and Esteban Prieto, 2016, "Time Variation in Macro-Financial Linkages," Journal of Applied Econometrics, Vol. 31, No. 7, pp. 1215-1233.

English, William, Skander van den Heuvel and Egon Zakrajšek, 2012, "Interest Rate Risk and Bank Equity Valuations," Finance and Economics Discussion Series 201-226, Board of Governors of the Federal Reserve System.

Estrella, Arturo, Anthony Rodrigues and Sebastian Schich, 2003, "How Stable is the Predictive Power of the Yield Curve? Evidence from Germany and the United States," Review of Economics and Statistics, Vol. 85, No. 3, pp. 629-644. 
Fry-McKibbin and Jasmine Zheng, 2016, "Effects of US Monetary Policy Shocks during Financial Crises - A Threshold Vector Autoregression Approach," Applied Economics, Vol. 48, No. 59, pp. 5802-5823.

Gilchrist, Simon and Egon Zakrajšek, 2012, "Credit Spreads and Business Cycle Fluctuations," American Economic Review, Vol. 102, No. 4, pp. 1692-1720.

Hartmann, Philipp, Kirstin Hubrich, Manfred Kremer and Robert Tetlow, 2015," Melting Down: Systemic Financial Instability and the Macroeconomy," unpublished.

Hatzius, Jan, Peter Hooper, Frederic Mishkin, Kermit Schoenholtz and Mark Watson, 2010, "Financial Conditions Indexes: A Fresh Look after the Financial Crisis,", NBER Working Papers 16150.

Hubrich, Kirstin, Antonello D’Agostino, Marianna Cervená, Matteo Ciccarelli, Paolo Guarda, Markus Haavio, Markus, Philippe Jeanfils, Caterina Mendicino, Eva Ortega, and Maria Teresa Valderrama, 2013, "Financial Shocks and the Macroeconomy: Heterogeneity and Non-Linearities," Occasional Paper Series 143, European Central Bank.

Hubrich, Kirstin and Robert Tetlow, 2015, "Financial Stress and Economic Dynamics: The Transmission of Crises, ” Journal of Monetary Economics, Vol. 70 (March), pp. 100 115.

International Monetary Fund, 2015, “Monetary Policy and Financial Stability,” IMF Policy Paper, September 2015.

Irving Fisher Committee, 2015, "Indicators to Support Monetary and Financial Stability Analysis: Data Sources and Statistical Methodologies," IFC Bulletins, Bank for International Settlements, No. 39.

Jiménez, Gabriel, Steven Ongena, José Luis Peydró and Jesús Saurina, 2014, "Hazardous Times for Monetary Policy: What do Twenty-Three Million Bank Loans say About the Effects of Monetary Policy on Credit Risk-Taking?" Econometrica, Vol. 82, No. 2, pp. 463-505.

Kaufmann, Sylvia and María Teresa Valderrama, 2010, "The Role of Credit Aggregates and Asset Prices in the Transmission Mechanism: A Comparison Between the Euro Area and the USA," Manchester School, Vol. 78, No. 4, pp. 345-377.

Krippner, Leo, 2015, “Zero Lower Bound Term Structure Modeling. A Practitioner's Guide," Palgrave Macmillan.

Li, Fuchun and Pierre St-Amant, 2010, "Financial Stress, Monetary Policy, and Economic Activity," Bank of Canada Review, 2010 (Autumn), pp. 9-18.

Mehl, Arnaud, 2009, "The Yield Curve as a Predictor and Emerging Economies," Open Economies Review, Vol. 20, No. 5, pp. 683-716. 
Metiu, Norbert, Björn Hilberg and Michael Grill, 2015, "Financial Frictions and Global Spillovers," Discussion Papers 04/2015, Deutsche Bundesbank Research Centre.

Peek, Joe and Eric Rosengren, 2013, "The Role of Banks in the Transmission of Monetary Policy," Research in Economics, Vol. 70, No. 3, pp. 262-280.

Pesaran, Hashem and Ron Smith, 2016, "Counterfactual Analysis in Macroeconometrics: An Empirical Investigation into the Effects of Quantitative Easing," CESifo Working Paper Series 3879.

Saldías, Martín, 2013, "Systemic Risk Analysis Using Forward-Looking Distance-to-Default Series," Journal of Financial Stability, Vol. 9, No. 4, pp. 498-517.

Silvestrini, Andrea and Andrea Zaghini, 2015, "Financial Shocks and the Real Economy in a Nonlinear World: A Survey of the Theoretical and Empirical Literature," Bank of Italy Occasional Papers No. 255.

Smets, Frank, 2014, "Financial Stability and Monetary Policy: How Closely Interlinked?" International Journal of Central Banking, Vol. 10, No. 2, pp. 263-300.

Spiegelhalter, David, Nicola Best, Bradley Carlin and Angelina van der Linde, 2002, "Bayesian Measures of Model Complexity and Fit," Journal of the Royal Statistics Society, Series B (Statistical methodology), Vol. 64, No. 4, pp. 583-639.

Stein, Jeremy, 2013, "Overheating in Credit Markets: Origins, Measurement, and Policy Responses" speech given at the Federal Reserve Bank of St. Louis, St. Louis, February 2013.

Wright, Jonathan, 2012, "What does Monetary Policy do to Long-Term Interest Rates at the Zero Lower Bound?” The Economic Journal, Vol. 122, No. 564, pp. F447-F466. 